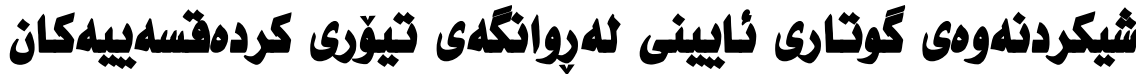

شيَروان حسين حمد

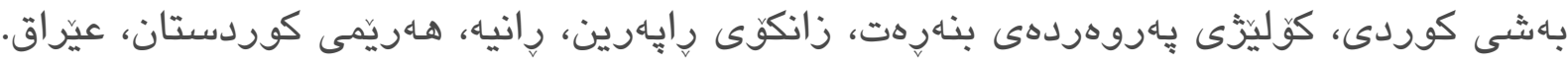
ئيمهيل: sherwan983@uor.edu.krd تهلار صباح عمر

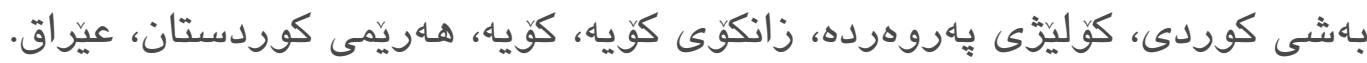
talar.sabah@koyauniversity.org ئيمهيل:

\section{:}

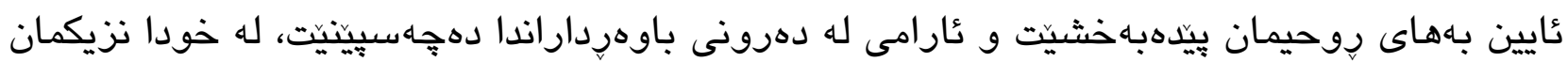

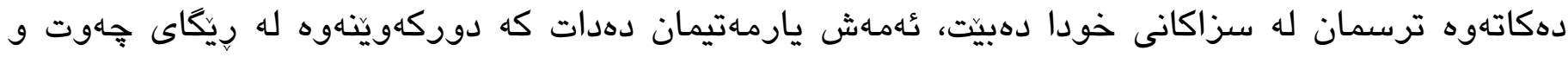

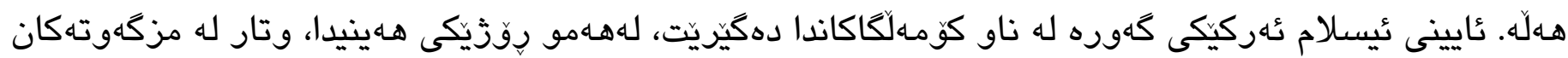

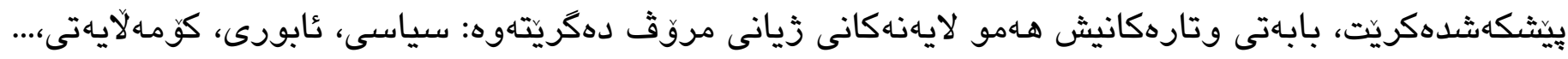

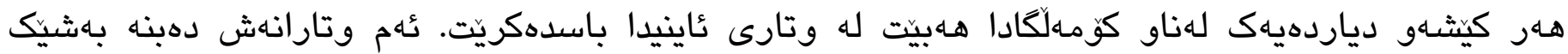

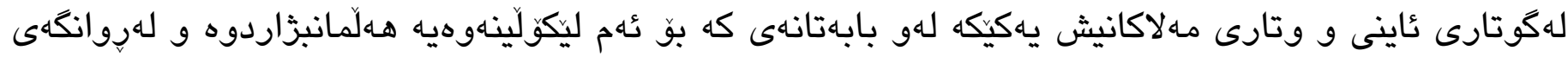
كردهقسهييهكانهوه شيكردنهوهيه بو وتاريكى (مهلا ئاراز) دهربارهى ئيدانهكردنى هيّرشى توركيا بو سهار

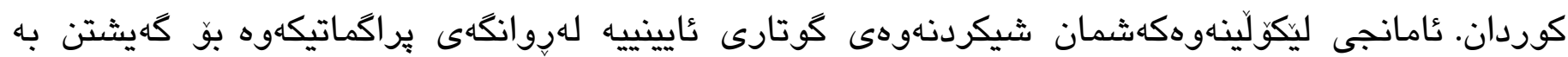
ئامانجهكهمان پيهيرهى ريّيازى وهسفى شيكاريمان كردوه، نمونهكهمان له كورته وتاريكى (مهلا ئاراز)

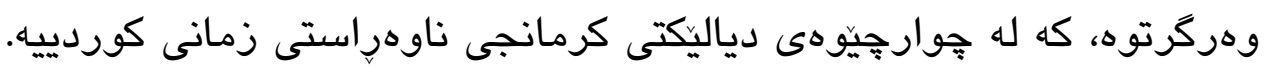

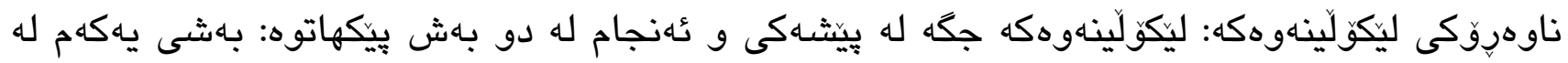

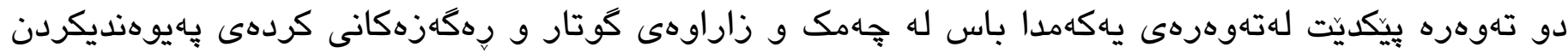

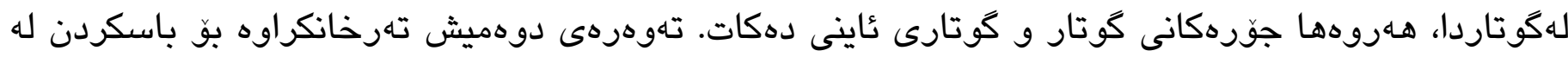

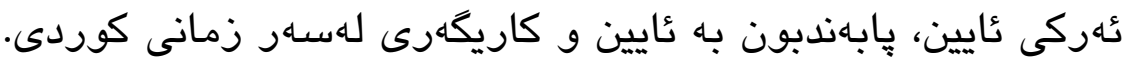

بهشى دوهم تهرخانكراوه بو باسكردنى لهسار تيؤىى كردهقسهييهكان باس له كردهقسهييهكان و

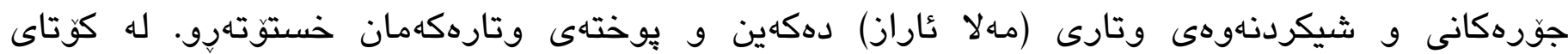

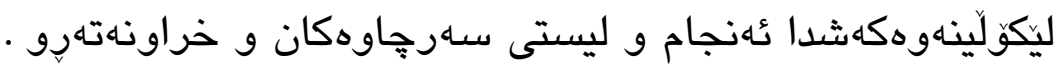

كاليله وشُلهكان: تيوّى كرددقسهيهكان ، كوتارى ئاينى، شيكردنهوهى كوتار، براكماتيك. 


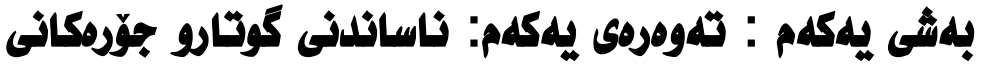

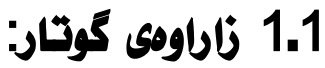

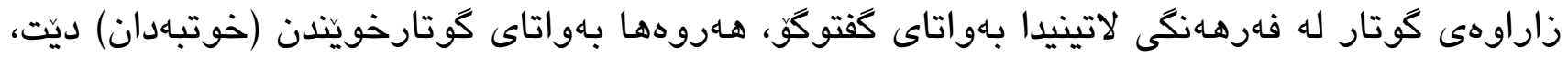
لهئهدهبياتى نويثيدا بو يهكهمجارلاى هايمز نامازهى بوّكراوه. (عهلى 2019: 19ـ 20) زاراوهى كوتار جههمكيكى

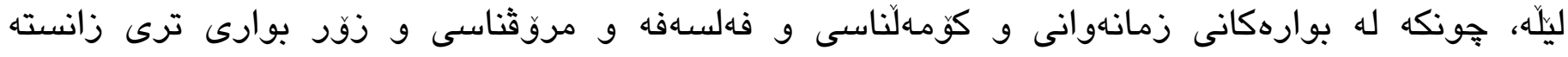

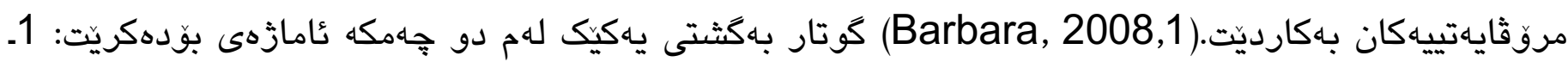

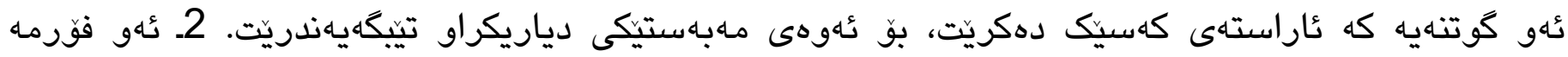
زمانييهيه كه دهكهويته سهروى رِسته. (عهلى 2019: 20) لهبهرئهوه دهبينين كه به پههندين شيّوهى جياجيا يّناسـى كوتاركراوه:

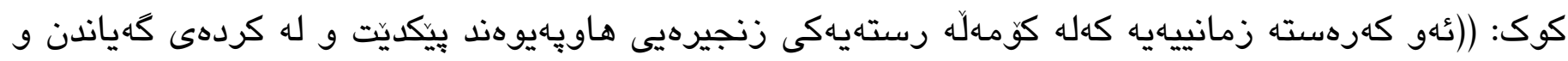

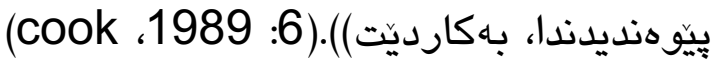

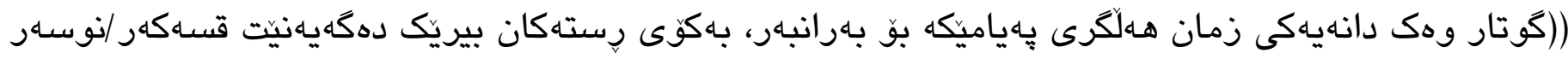
كُهم بيره دهشكينيت و دابهشى سهار رستهكانى دهكات.)) (ئهين 2009: 34) هاريس ((يهكهيهكى زمانى كَهورهيه، يان كومالّه رستهيهكى زنجيرهييه)). لاع هاريس كوتار رستهيه لهيهكهيهكى

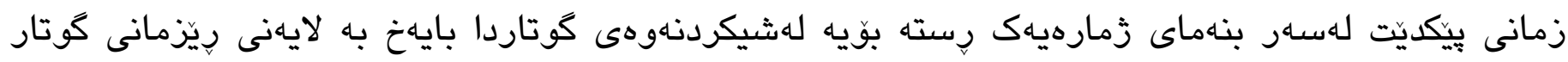
دهدات.( محى الدين 2016: 8)

يان دهوتريّ، ((بريتييه له زنجيره رستهيهكى يهك لهدواى يهك كهله ئاكامدا ماهييهت و بونى خوّى

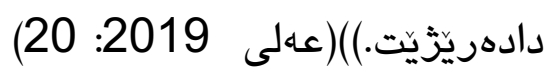

كهواته كوتار زنجيرهيهك رِستهى هاويهيوهندن بّ كَهياندنى يهيام و مهابهستيك بهكارديّت. واتاى كوتاريش

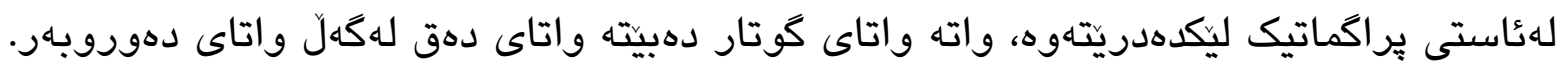

\section{1}

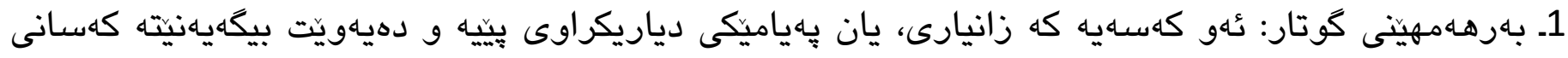

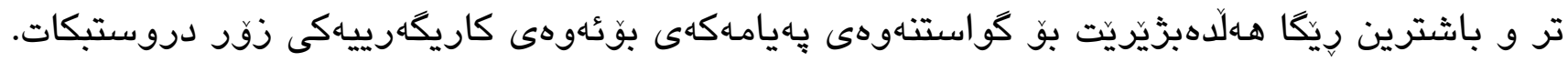

2- وهركرى كوتار: تُهو كهسهيه، كه يهيامهكه وهردهكريت. وهركرى كوتار زياتر لهوهى كه بهتهنها وهركرى كوتار بيت، كاراو هاوبهشيشه لهدروستكردن و دياريكردنى واتاى ناخاوتن، وهركرى كوتار، واتا بهريگًاى راستهوخٌ و ناراستهوخِ دروستدهكات. 


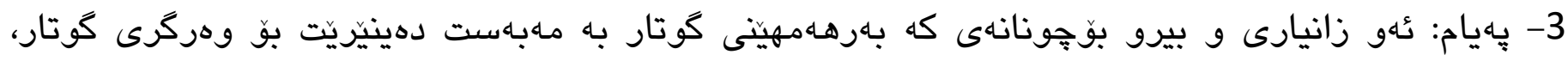

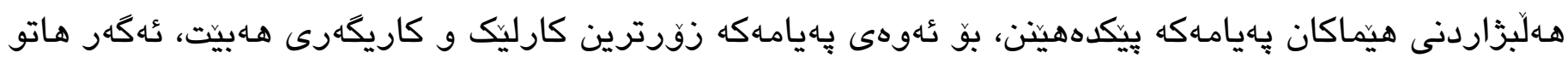

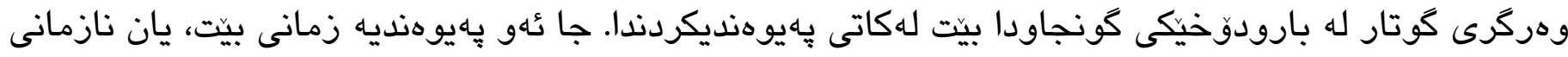

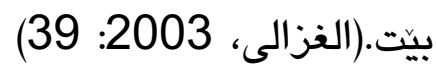

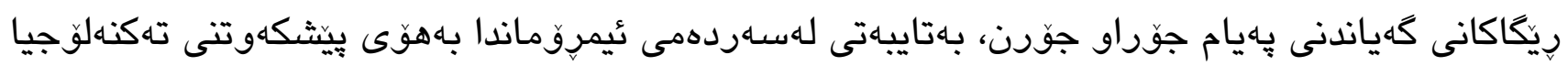

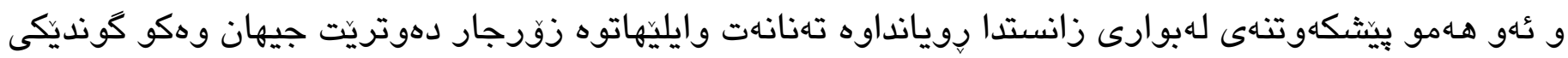

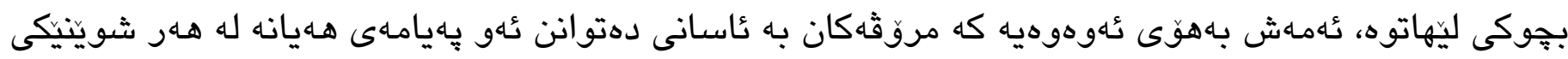

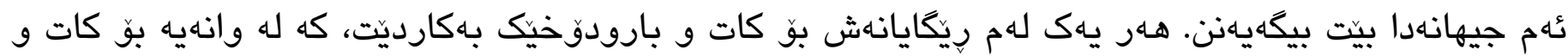

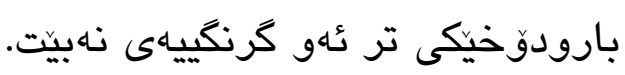

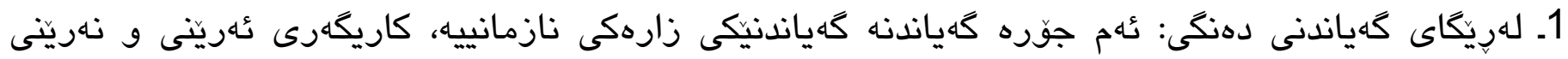

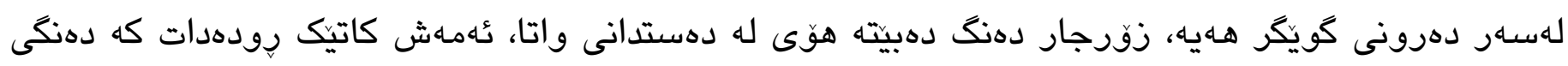

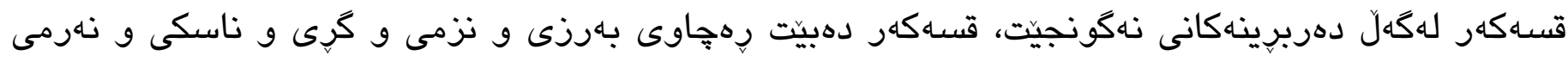

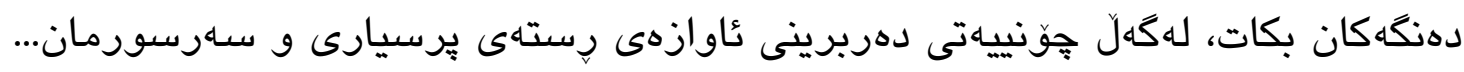

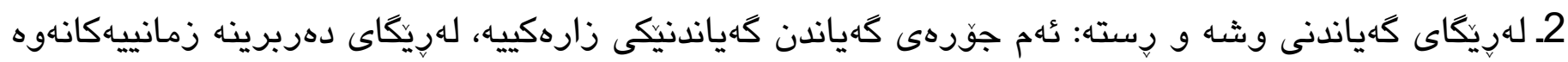

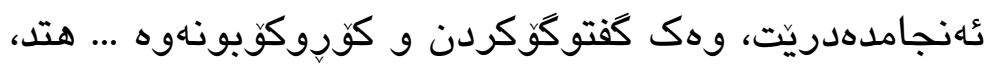

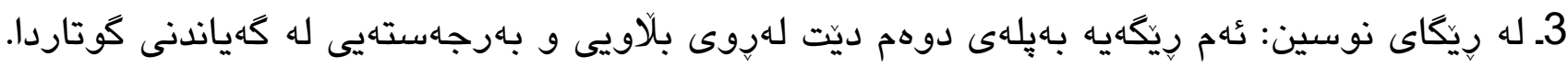

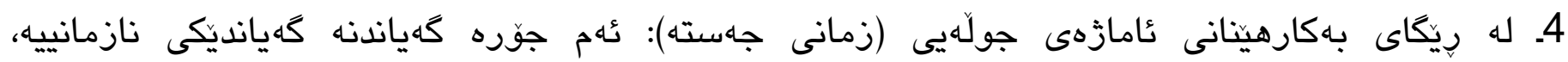

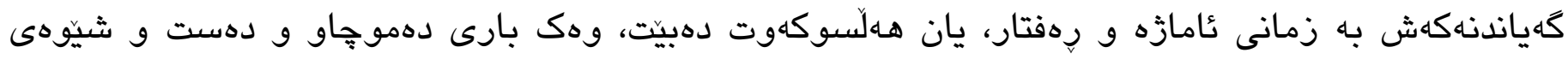

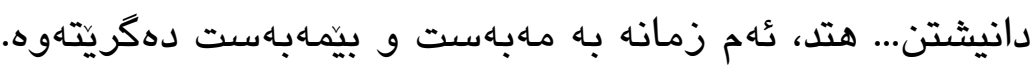

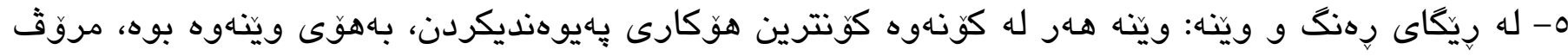

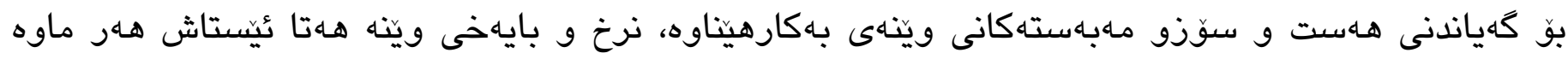

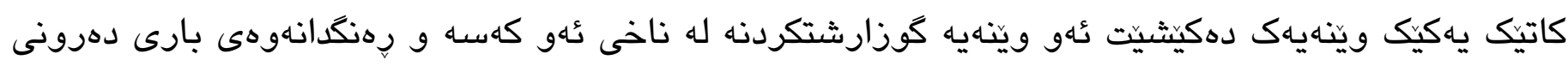

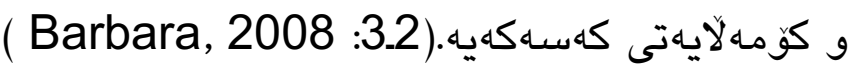

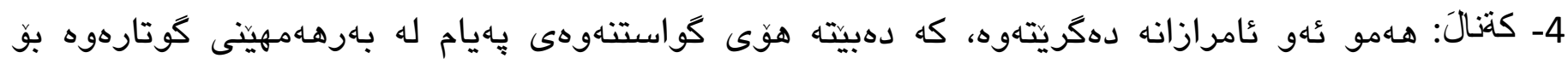

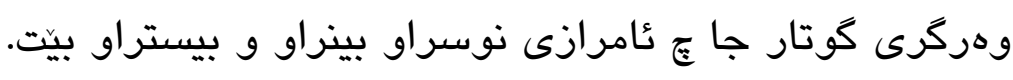

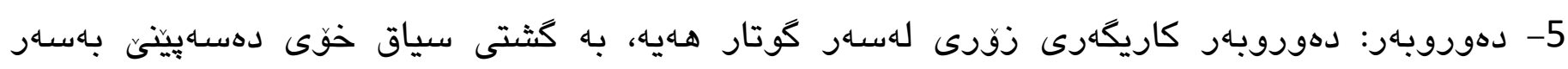

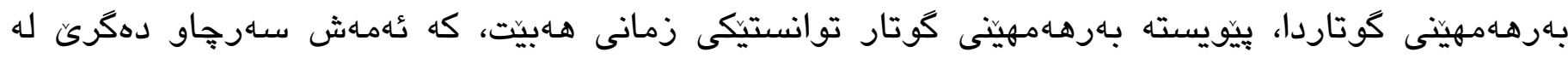


رِوّشنيريهكهى بو رِازيكردن وكارتيكردن توانستى كَهياندن بوّكَهشتن به ئامانجهكه و بهديهينانى پِيوهندى

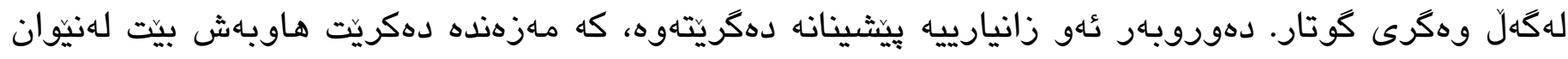

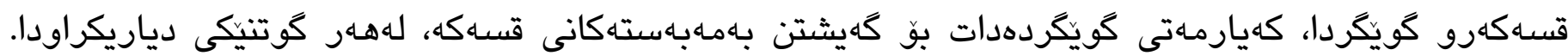

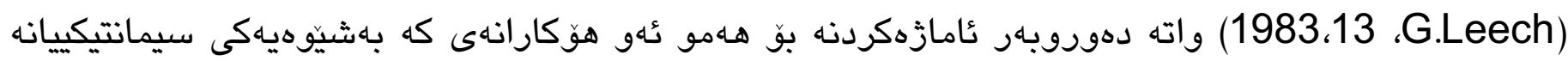
فورِم و واتا و كونجاندنى عاخاوتن ديارى دهكهن.

لهبارهى جوّرهكانى دهوروبهار ئامازهه به دو جوّرى سهرهكى دهوروبهر دهكريّ.

1ـ دهوروبهرى زمانى: ناوهوهى زمان دهكريتهوه، كه قسهكهر بوّليكدانهوهى مهابهتى رسته دهربردراوهكان

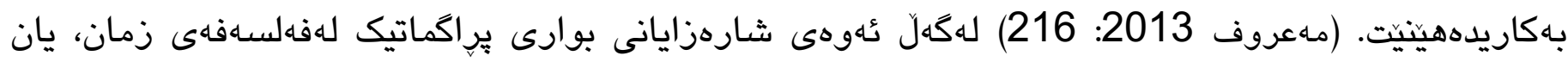

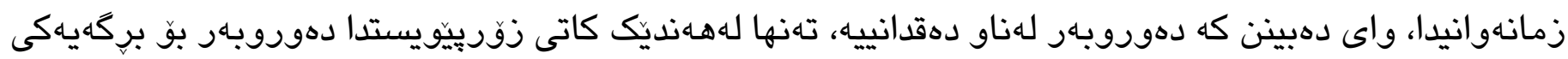

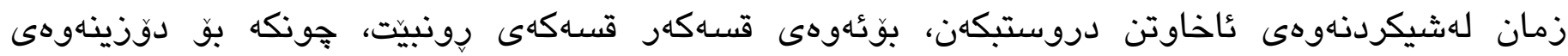

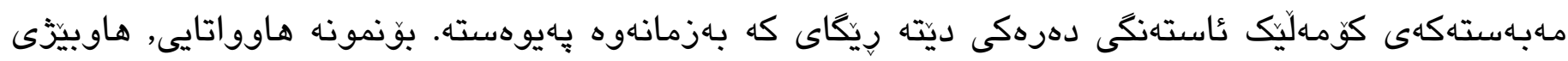

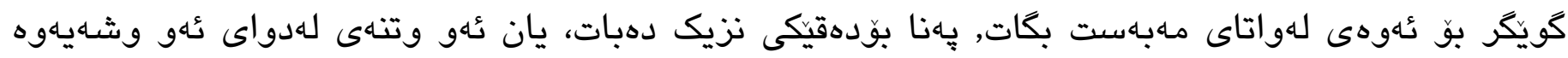

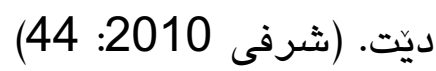

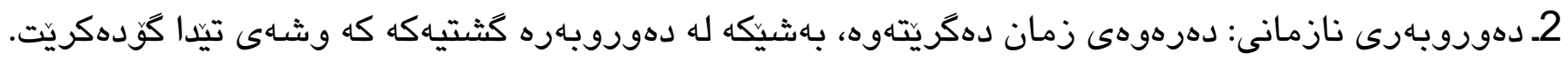

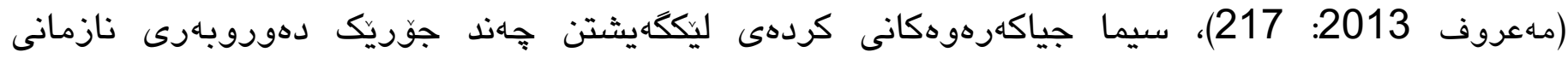
دياريدهكهن(مه حمود 2009: 12).

1ـ دهوروبهرى دهرونى: ئهم جوّره دهوروبهره هـمو ئهو هـلّهون و داجِونه دهرونيانه دهكريتهوه كه قسهكهر

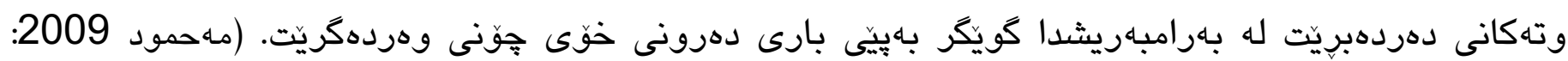

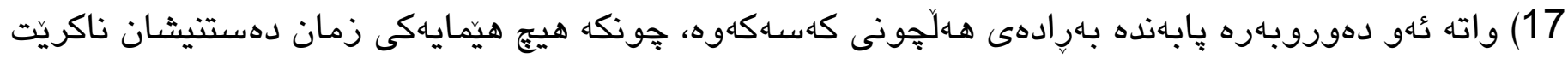

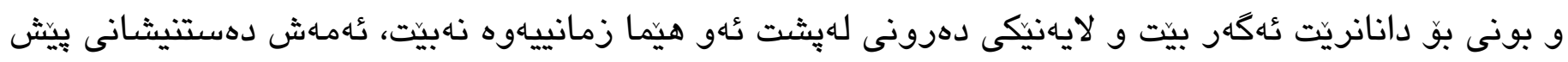

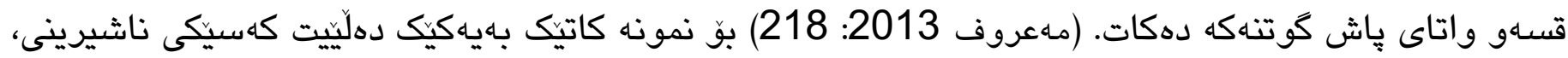

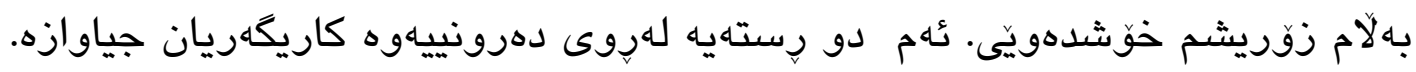

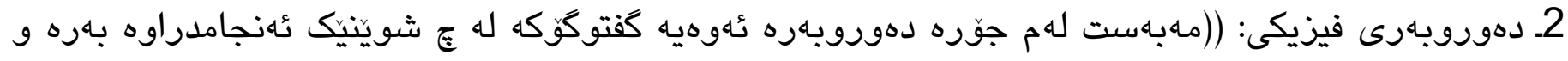

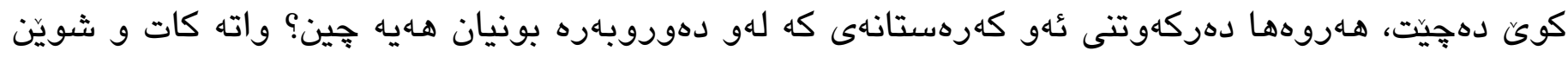

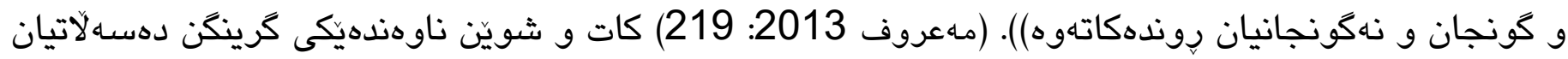

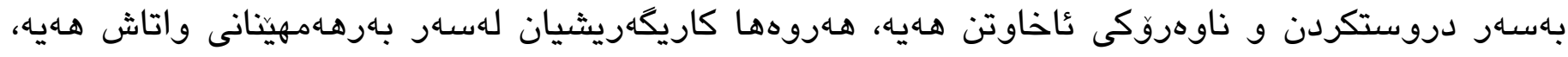

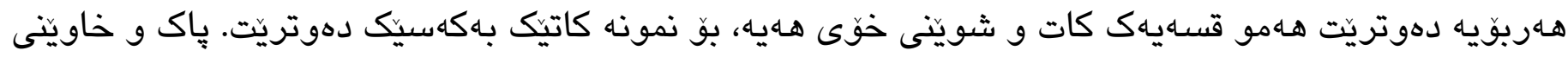

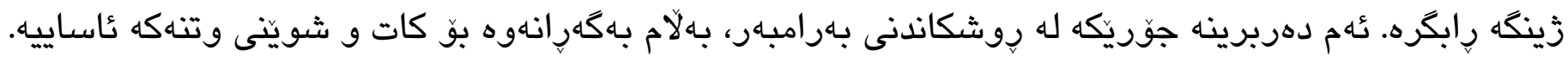


3ـ دهوروبهرى كهلتورى: زانيارى دونياييه هاوبهشهكانه كه لهلايهن قسهكهرو كويكُرهوه زانراوه. كتيبهكهت

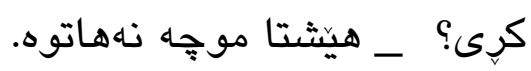

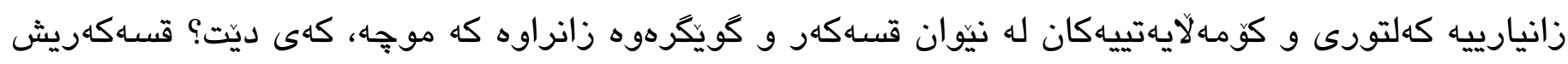

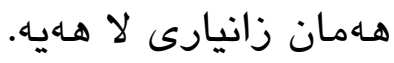

\section{1 تابيلتيبهكاذى كمتار}

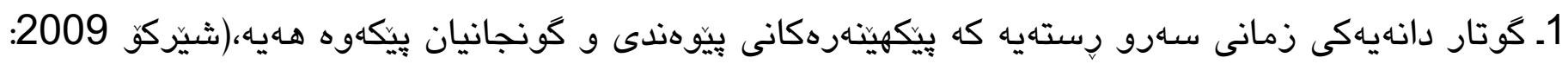

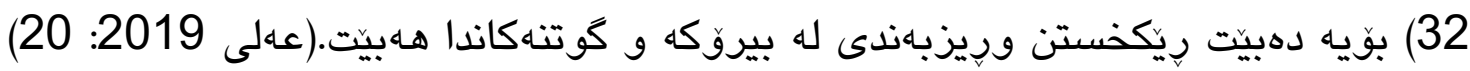

2. كوتار، سيستميكى كوتهيه، جهختكردنهوه له سيماى كوتهى كوتاريش له بنهرهتدا لهكاركردنى زمانهكانهوه له زمانى عاخاوتناوه سهارجاوه دهكريّت.

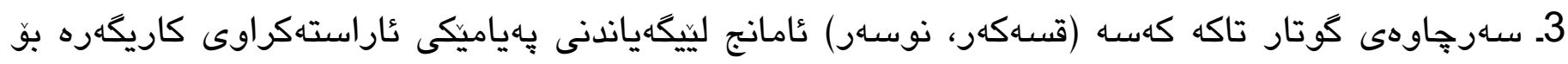
كوينكرو خويناه.

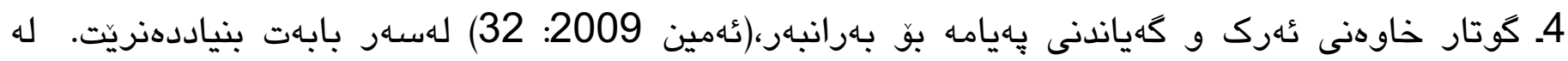

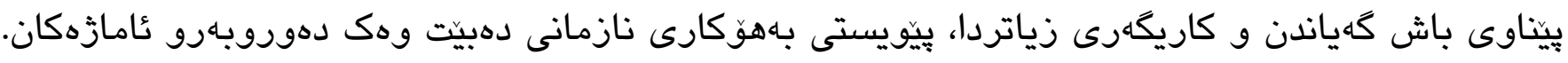

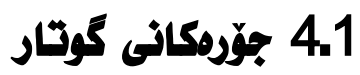

كوتار فرهرههانده زوّر جوّىى جياواز لهخودهكريت، وهك: كاروبارى سياسى، كارويارى كومالآيهتى،

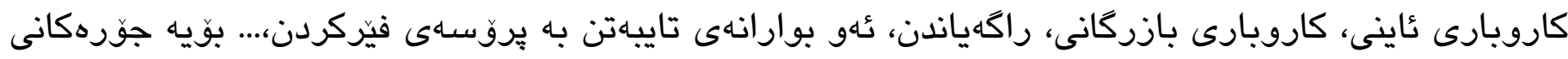

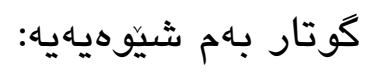

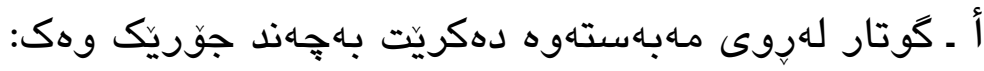
كوتارى زانستى بابهته زانستييهكان كوتارى ئايينى كوتارى ئهدهبى

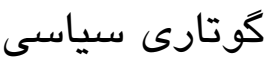




\section{1}

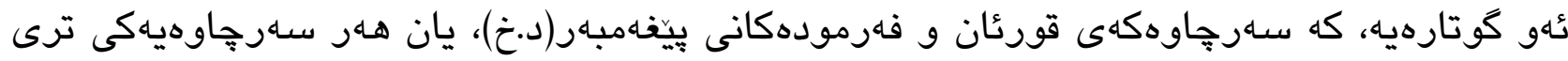

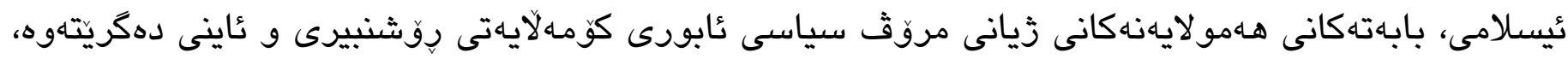

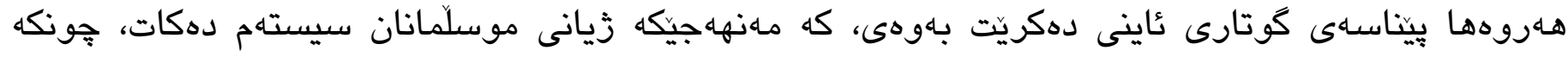

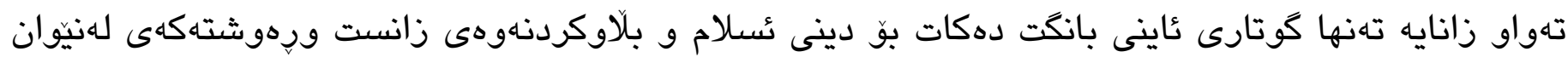

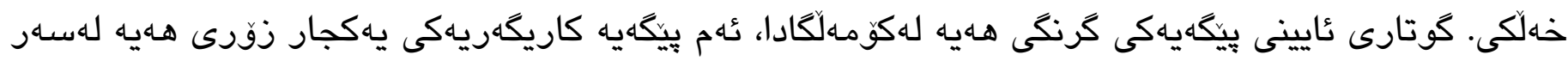

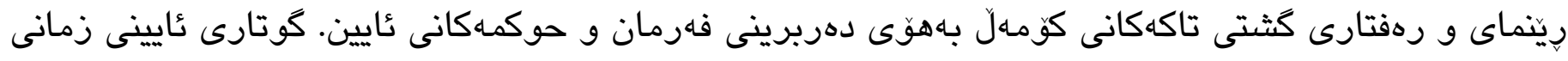

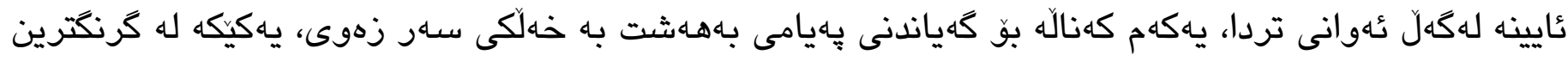

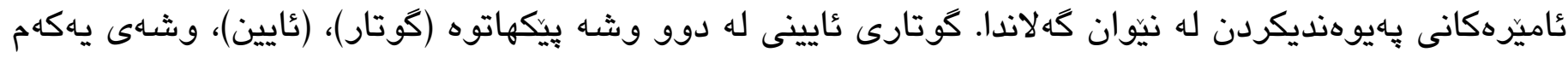

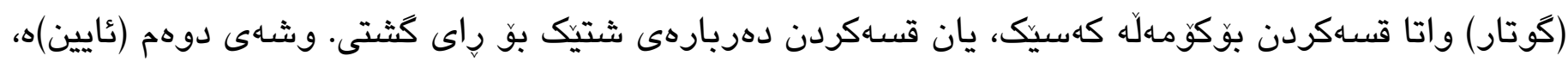

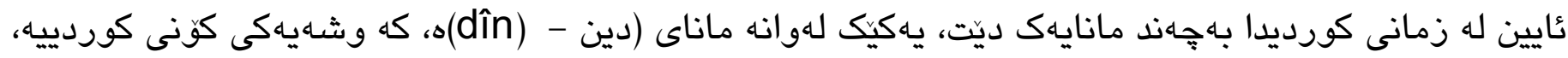

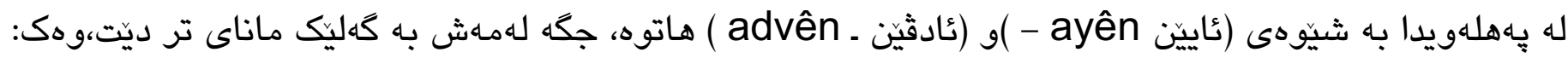

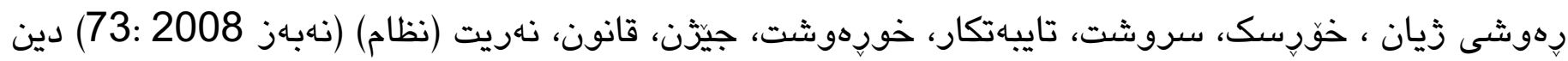

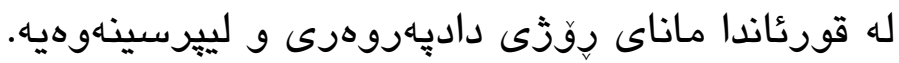


ئايينهكان به دريّزايى ميَّوىى مروّثايهتى كاريكهريان لهسهر زيانى مروقث دروستكردوهو دهيكهن،

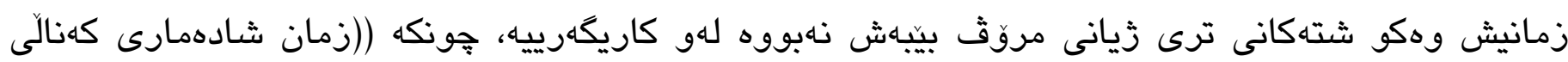

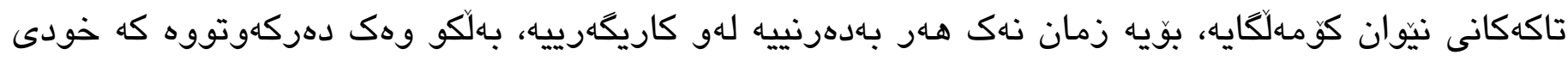

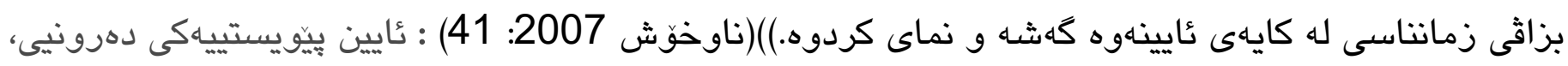

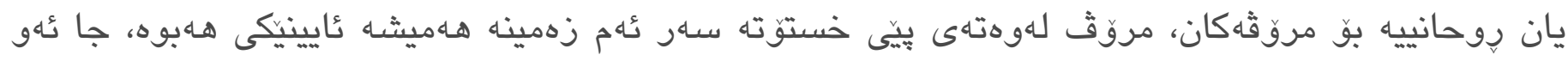

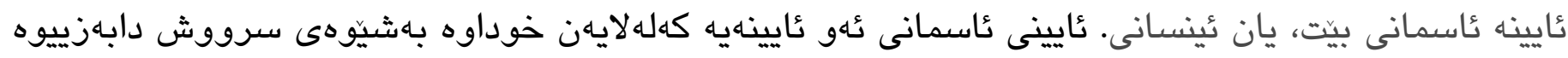

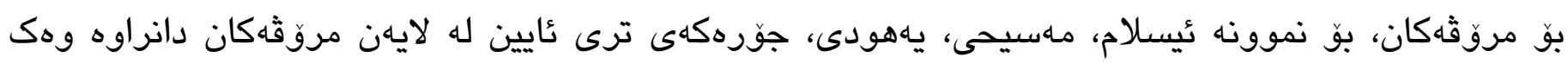

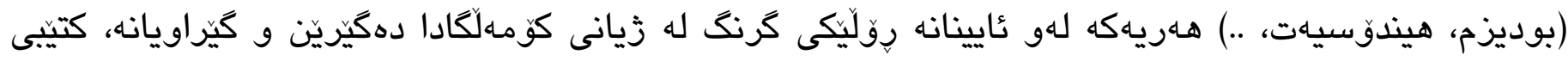

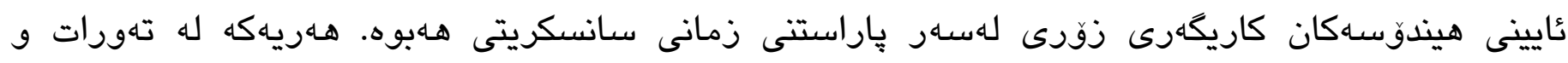

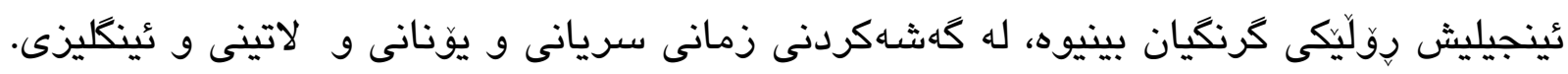

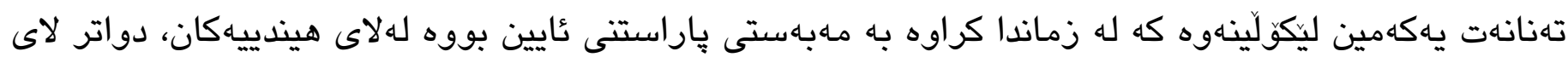

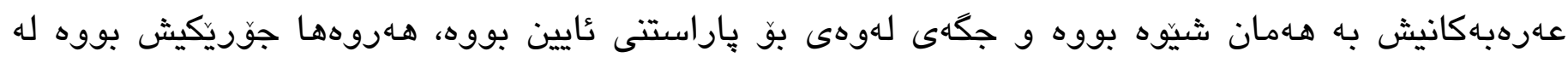
خودايهرست.

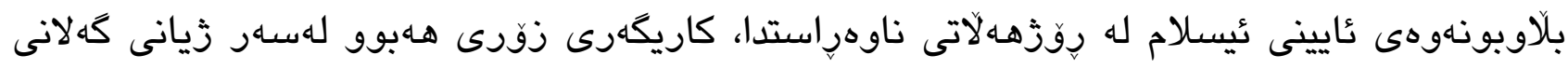

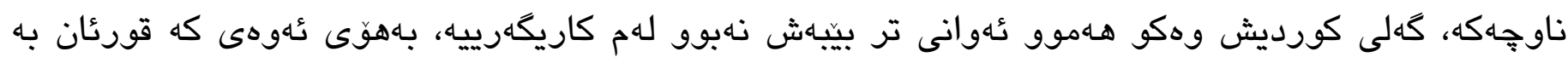

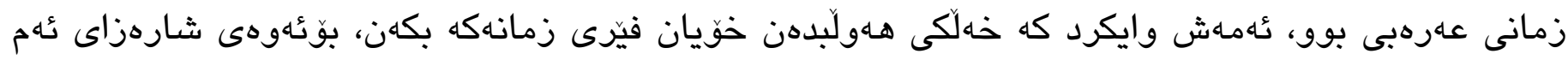

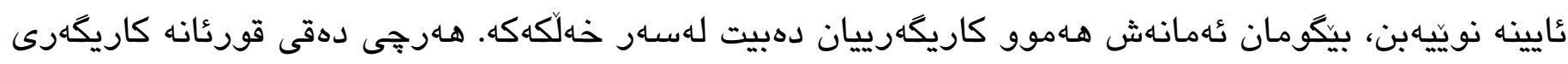

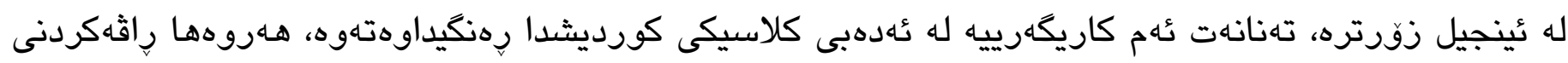

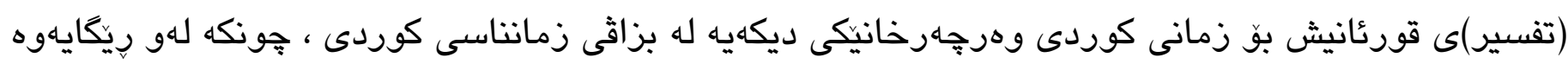

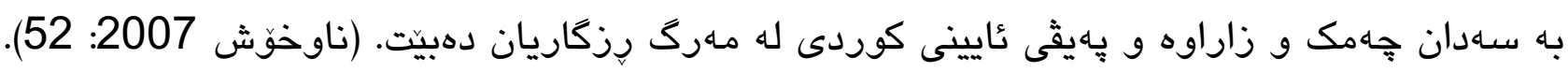

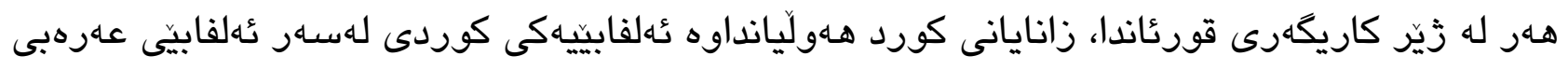

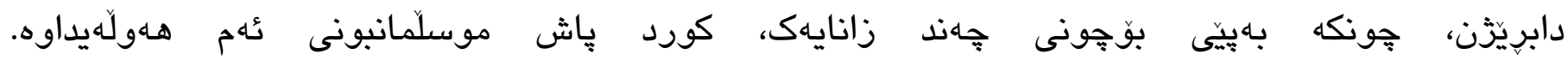

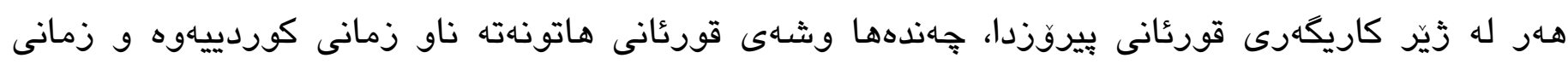

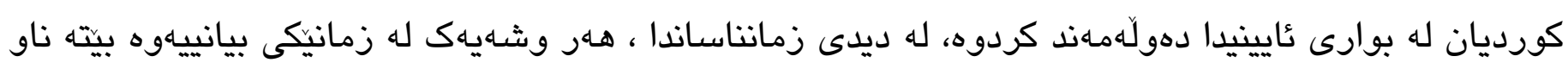

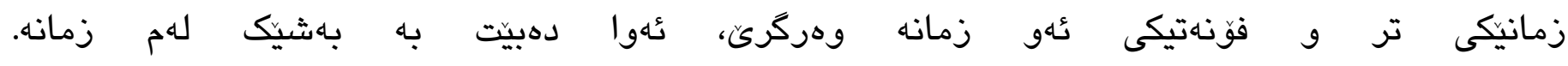

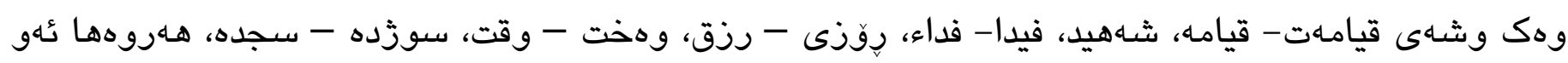

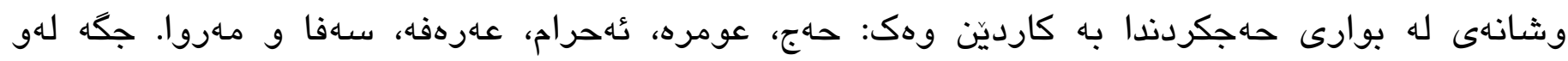




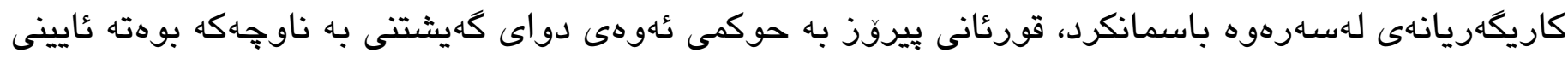
سـارهكى له كوردستان، شاعيرانيش (به تايبهتيش شاعيرانى كلاسيكى كوردى) وهكو جِين و تويزّهانى ترى

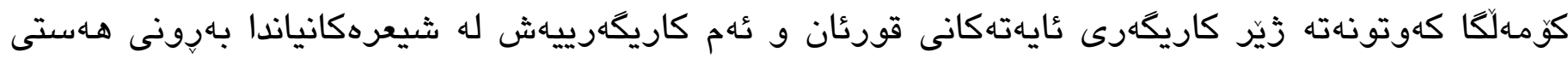

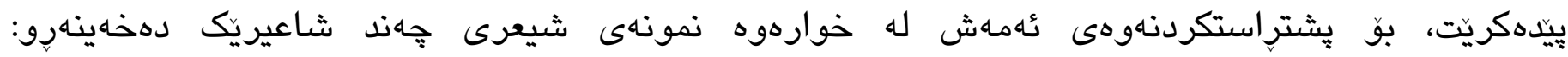

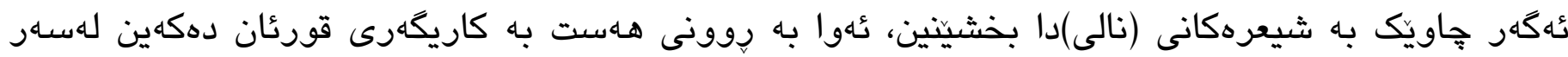
شيعرهكانى جا به شيّوهى رِاستهوخو بيّت، يان ناراستهوخٌ، وهك لهم شيعرانهى خوارهوهدا دهردهكهيّ: -موشاريرهف بوو به تهختى عارش و تاجى قوربى (عندالله)

بـه هـاءجى دهرجى (او ادنى) و (ما اوحى)ى قورئانه. (ديوانى نالى: 1976: 515) بـاه نارى عيشق و عاوى دل، جهسهاد وهك حهضرهتى موسا طهريقى بهحرى فيرعهون و ، رهفيقى. عاتهشى طووره.(ديوانى نالى: 1976 : 1976 هـروهها مـهحى كاريكَهى ئايين به ئاشكرا له شيعرهكانيدا دهردهكويّت، وهك لهم نمونانهى خوارهوه دهردهكهويَت:

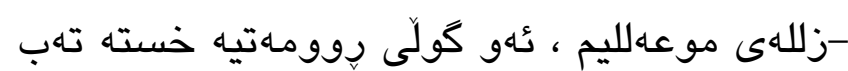

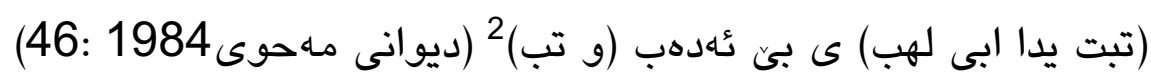

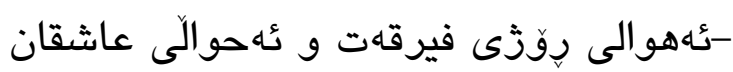
لهو روّزهدا موطا بيقييه (هل اتى حديث.... ) (ديوانى مـهوى

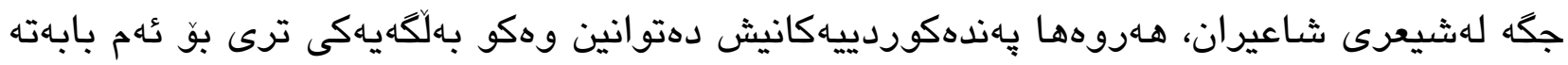

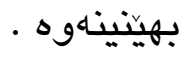
-خوا كه كَيان و نان ئهدا بهم خهلكه.

\section{2}

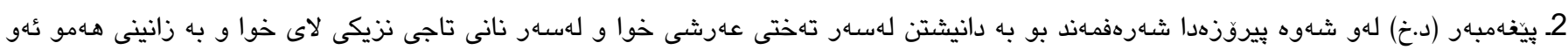

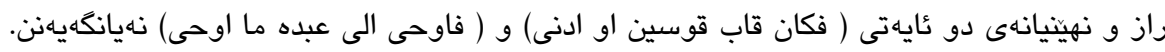

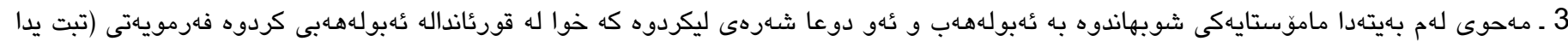

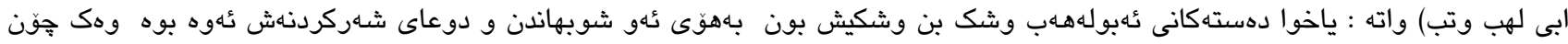

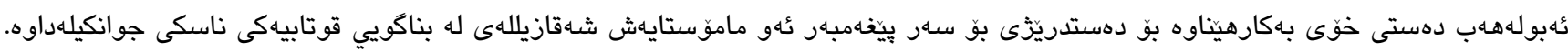

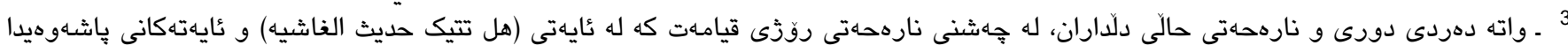


كردهقسـييهكان بوّجونيكه قسهردن به ئهنجامدانى كاريّك دادهنيّت(توفيق 1995: 38) شيكارى لهبارى

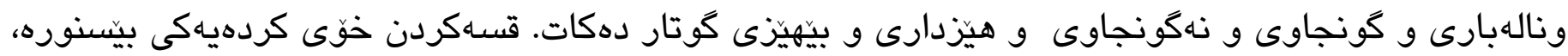

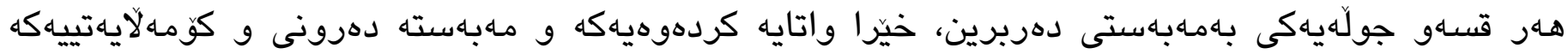

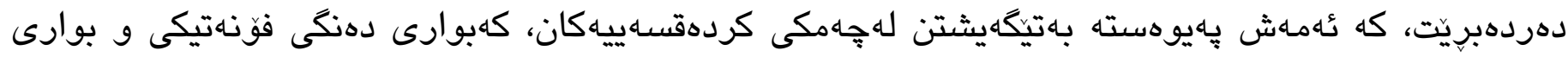

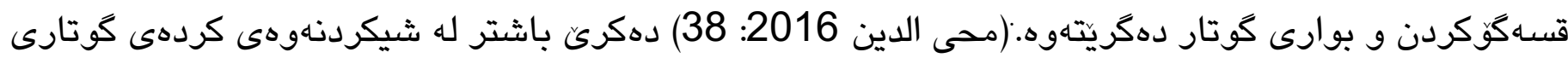

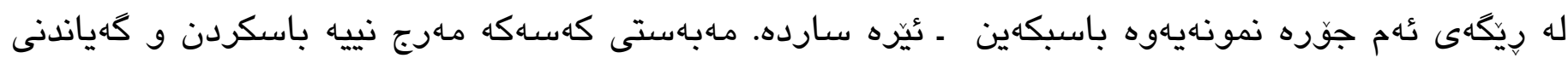

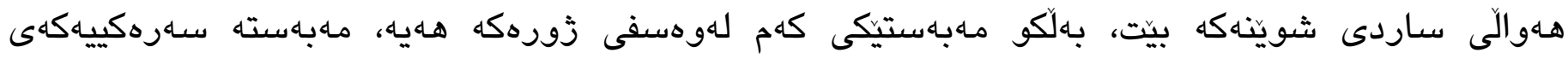
رإِهراندنى كاريكّه جا داوا ،سـرسورمان، بِرسيارى ... وهك

با ليَره نهخوينتين. (داوا)

خوينّدكاران نهخوشن.(كلهى)

$$
\text { كَرمكهرهوهكه داكيرسينتى.(داوا) }
$$

يان كردهيهكى قسهييه، كهواته ليّرهدا دو واتا بهرجهاهته دهبيت، يهكهميان فهرهـنكَه. دوهميان بهديهينانى كرده قسـييه بـاهباوهرى ئوستن كهخاوهنى تيوّرهكهيه قسهكهر لهدواندندا سيى كرده ئهنجام دهدات. كردهى كوتن كردهى مـبهست (illocutionarg act) كردهى ياشكار (post illocution act) (دزهيى (preillocution)

\section{2}

ئُستن دو جوّره كردهى خستوتهرو، كه بريتييه له كردهى ئاشكرا و كردهى شاراوه.

1. كردهى كأشكرا: عُهم جوّره كردهيه مـهبهست به رِاشكاوى و رِاستهوخٌ دهردهبريّت و كردهى رِوداو و

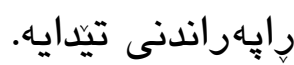

2. كردهى شـاراوه: دهربرينهانمان زورجار بهشاراوهى دهردهبردرين، دهربرينه شاراوهكان كه لهشيّوهى

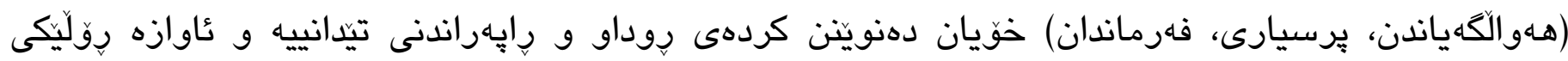
كرنكى تيادا دهكيّريّت.( دزهيى

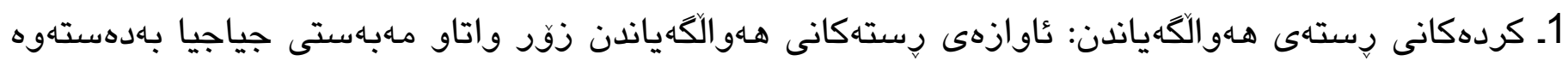
دهدات وهك كلهيى، نارهزايى، ياكانهكردن، بِّزشهينانهوه،...

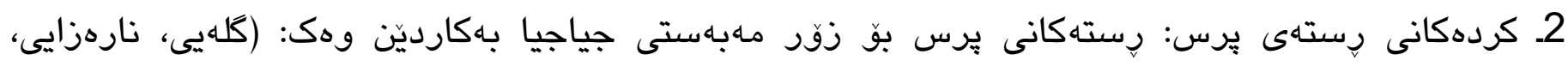

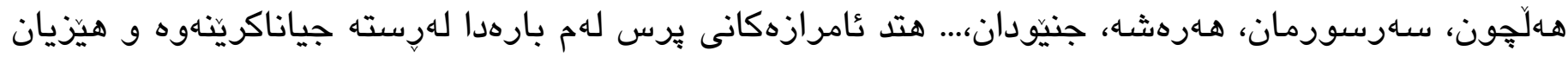


لهسهر نييه و وهستان لهنيّوان ئامراز و رِستهكان دانييه، هاموى بهيهك ئاوازه دهرددبردريت.(دزهيى 2011:

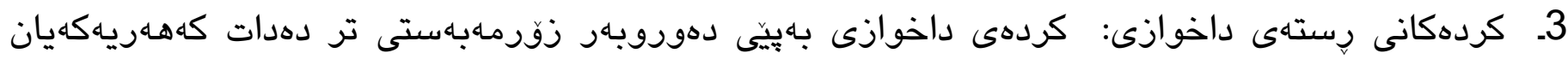

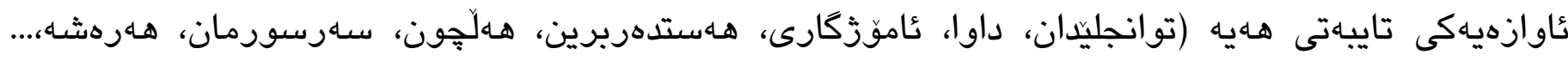

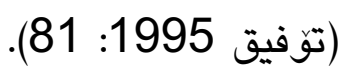

\section{2 كردمكانى كُوتن (بايومثلديكردن) و دوسلآتى كوتار}

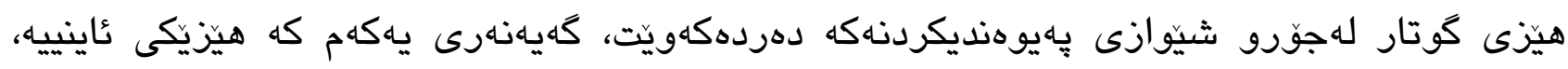

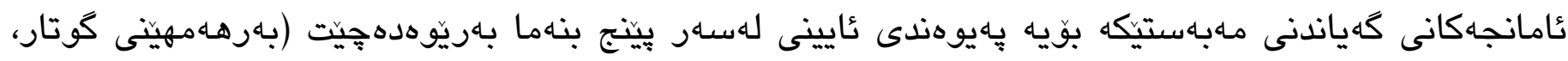

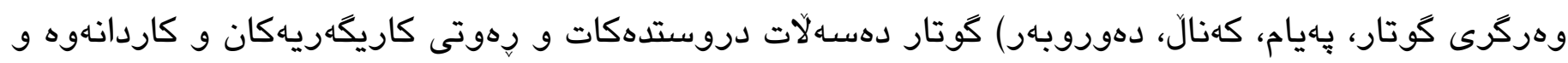

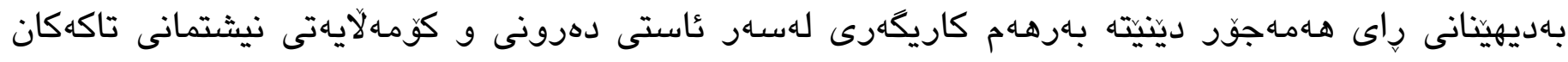

بهاديده هينين.

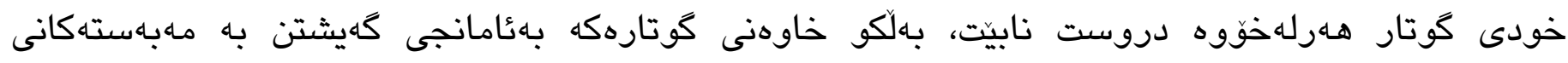

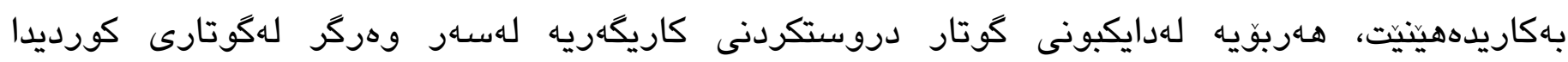

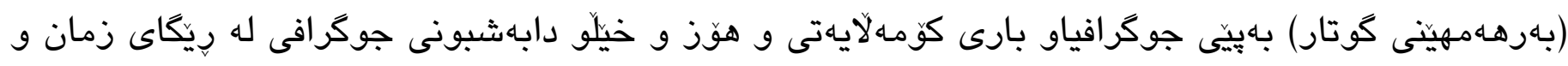

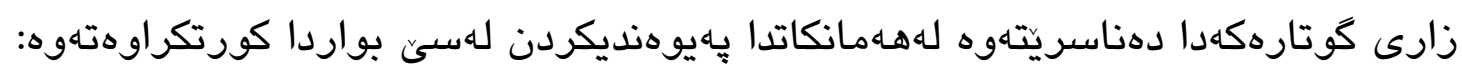

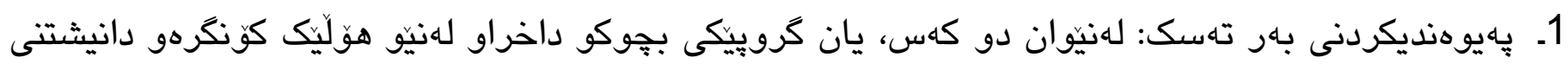
داخراو.

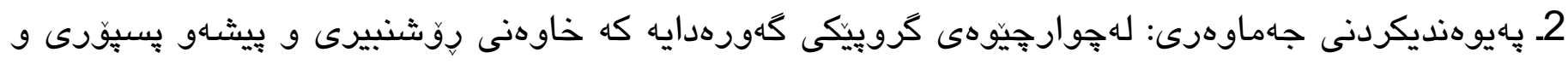
جينى كومهالآيهتى جياوازن.

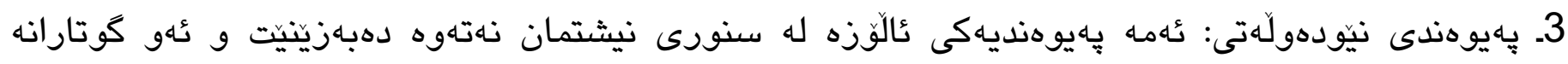

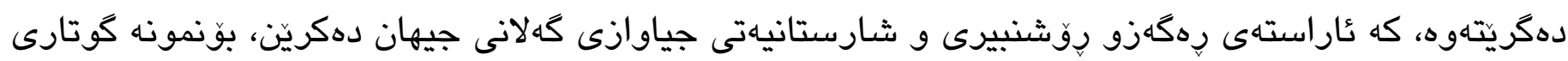

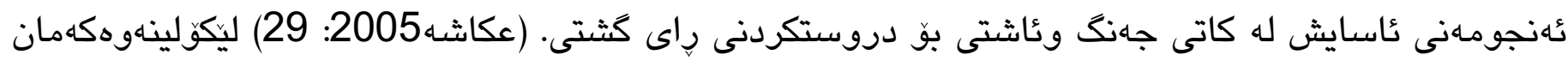

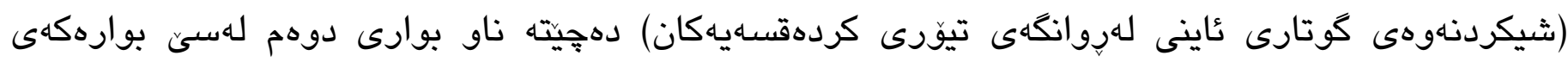

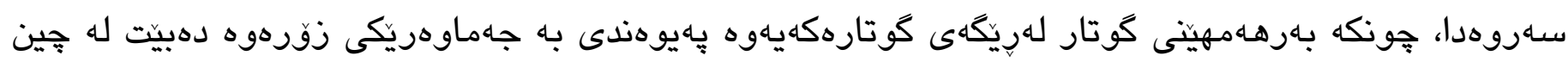

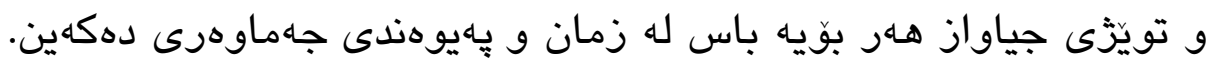




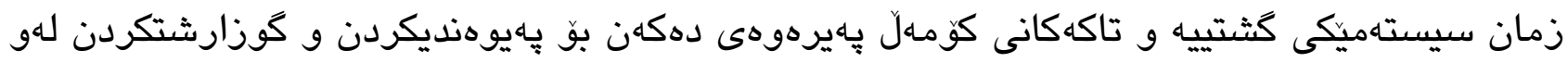

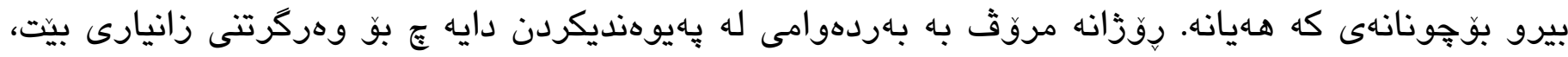

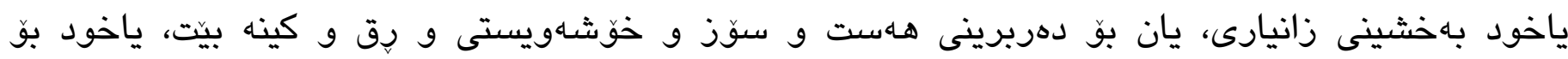

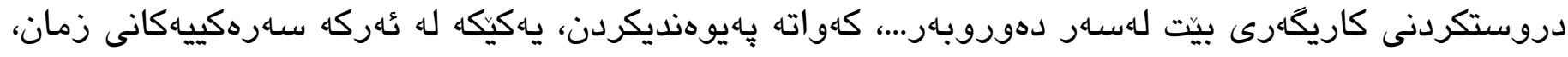

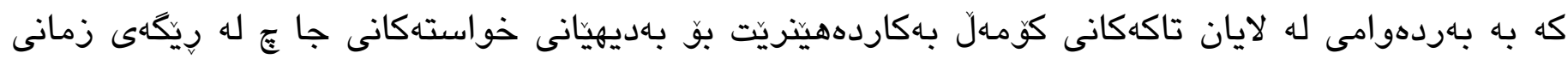
نوسراو، بينراو بيستراوهوه بيّت.

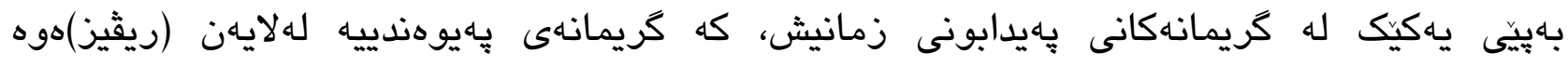

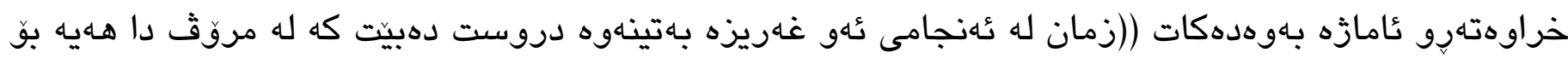

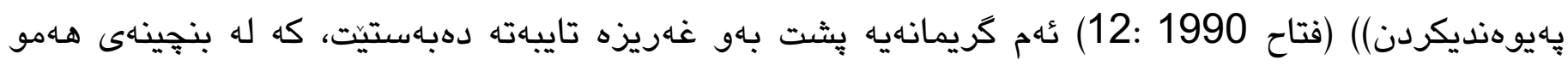

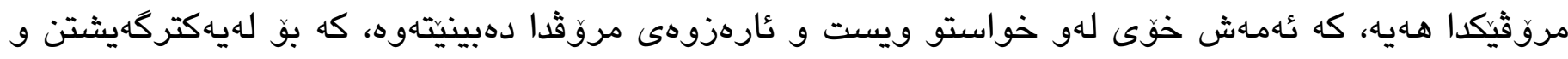

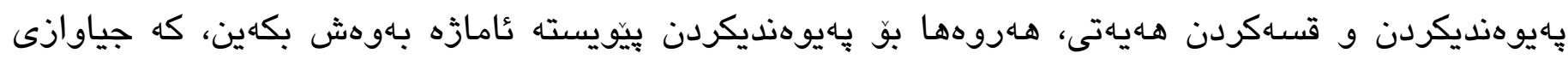

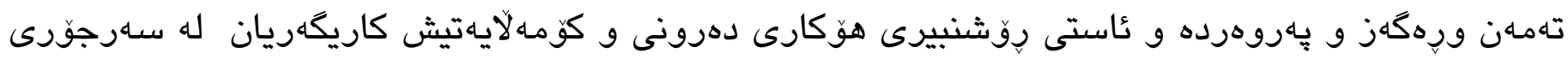

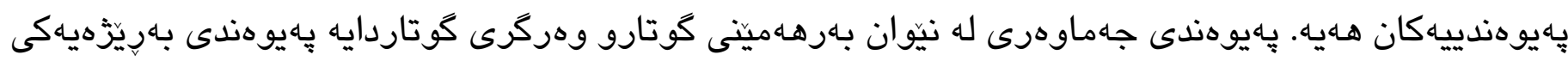

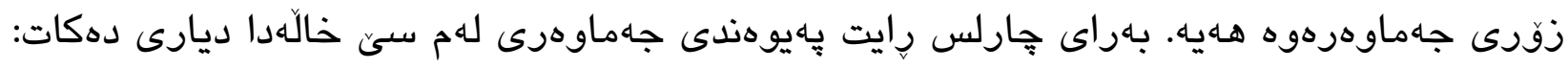

$$
\text { 1/ } 1 \text { عاراستهى جهماوهريّكى زوّر. }
$$

/2 پِيامهكه بهشيّوهيهكى عاشكرا دهكوازريتهوه لهيهك كاتدا دهكاته تاكهكانى جهماوهر.

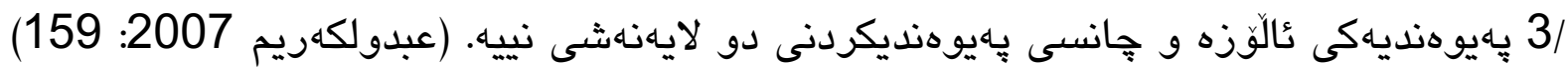

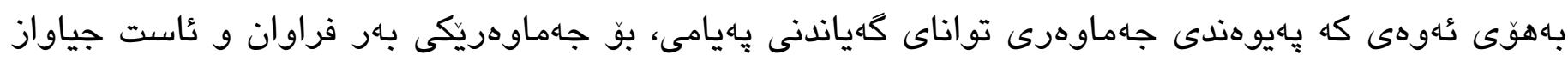

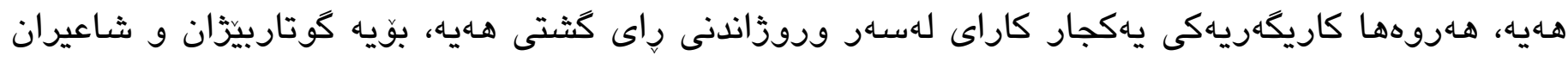

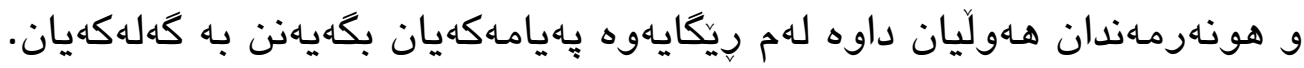




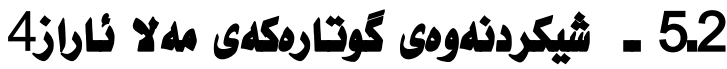

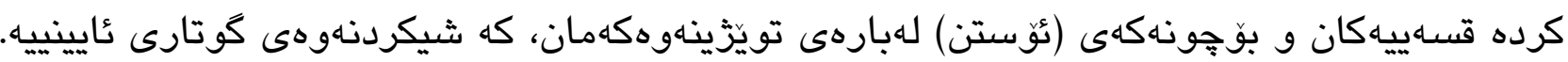
لهسهار بنهماى يراكماتيكى و تايبهت كرده قسهييهكان دهدويِين، سـاركهوتن له بهديهينانى كردارو بهاتالبونهوهى

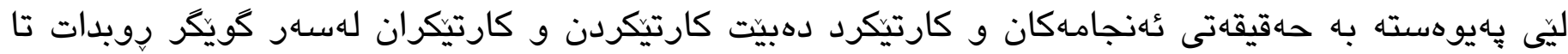

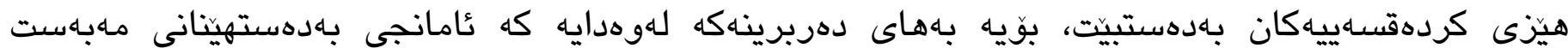
بكات.(محى الدين 2016: 42).

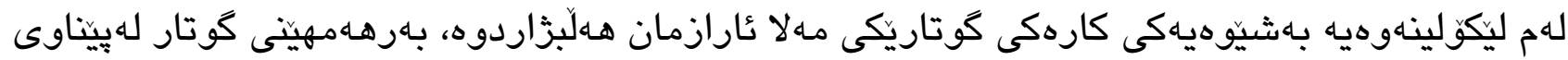

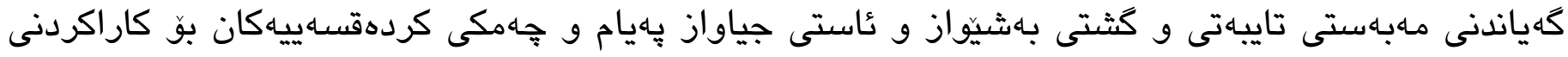

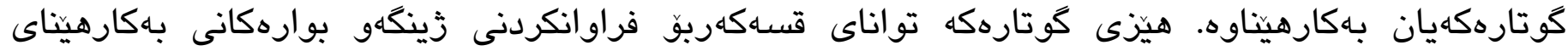

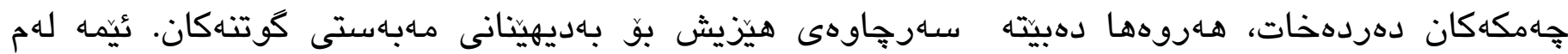

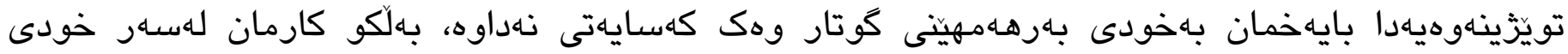
كوتارهكه و ئهو بوارانهى له كوتارهكهدا هـهيه و لهسهرى رِونراوه، واته ستراتيجى عُهم تويَزينهوهيه شيكردنهوهى

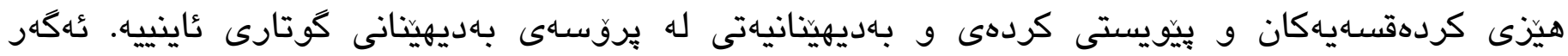
سـهيريكى ئهم كورته كوتارهى ماموّستا مـهلا عاراز بكهين دهربارهى ئيدانهكردنى هيَرشى توركيا بو سـاركوردان

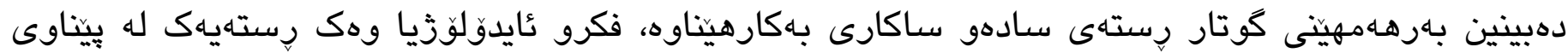

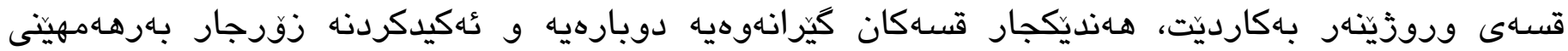

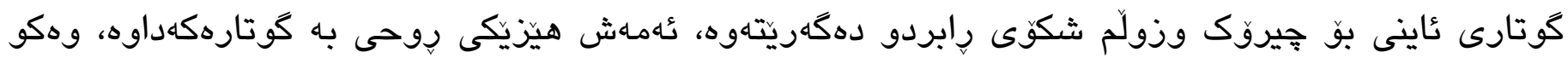

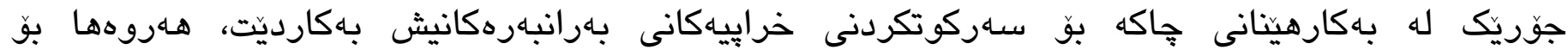
ورياكردنهوهى خهلكى يِيشـاندانى رِوى رِاستهقينهاى دهولّهتى توركياو ئهردوغان، كَوتارهكه لهروى ناوهروكهوه

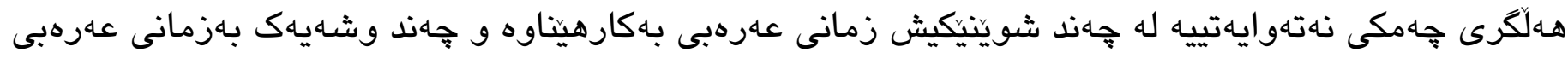

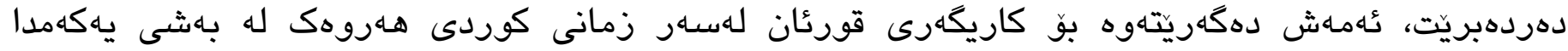

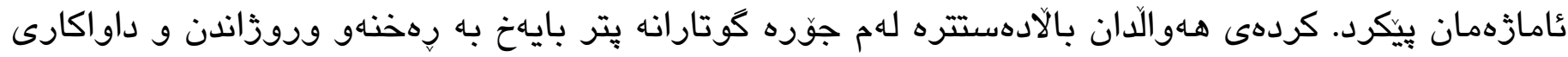
دهدهن تُهماه كاريّكى كاساييه.

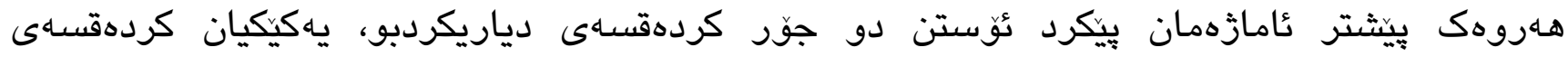
رِاستهوخٌ بو، كه لهم جوّره كردهيه مـهبهست به رِاشكاوى و رِاستهوخٌ دهردهبِدرا. جههندين جار كردار دوباره دهكاتهوه ئهو كردارانهى، كهلهم كوتارهدا دياريكراون بريتييه له(90) كردار (51) كردارى رِانهبردوه (25)

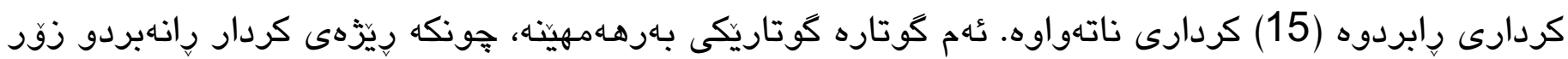


زياتره له ريّزهى كردارى رِابردو، كردارى رِانهبردو يّلان و ثُامانج و دنيا بينينى تيّايه بوّ داهاتو، هـروهها بكهرى كردارهكانيش رِون و ئاشكرايه ئهم جوّره كوتارانهى كه بكهرى كردارهكانى رِون و عاشكرا بن عئها

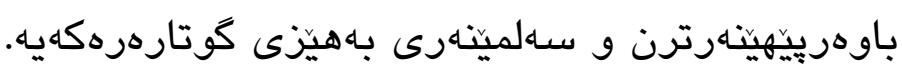

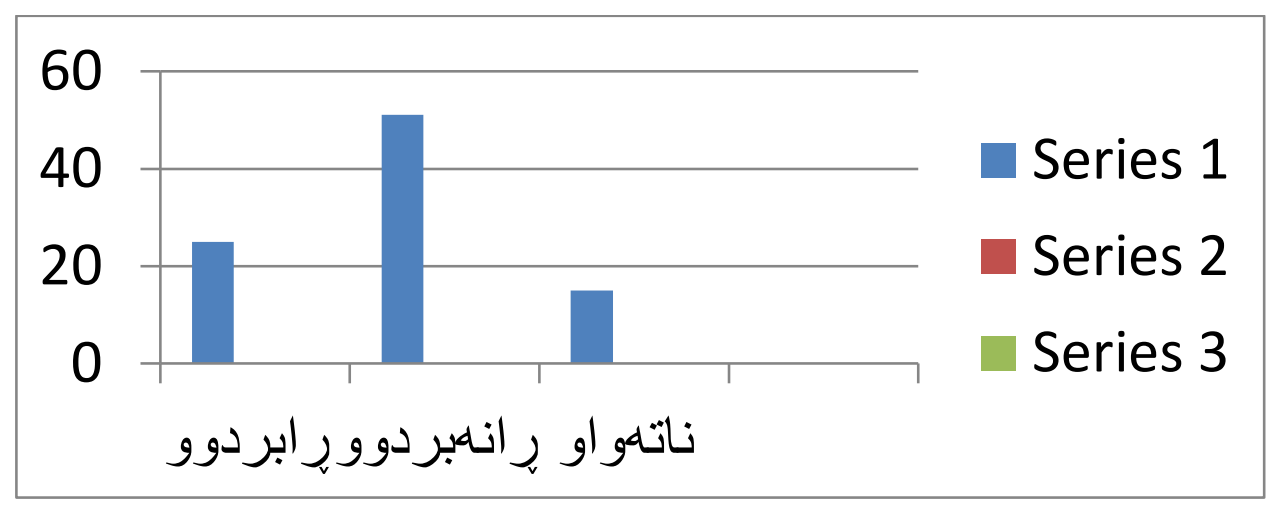

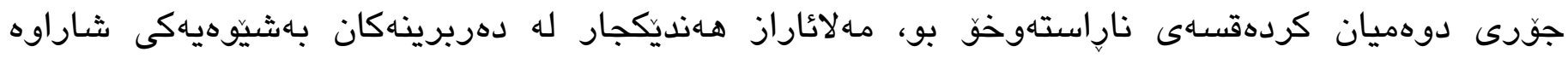

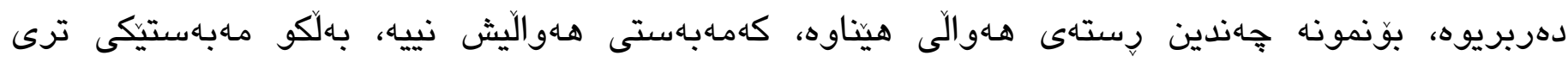
لهيشتهوهيه.

خوداى كَوره بهكوردى خهلقّمى كردوه. (ههستدهربرين) كُهو مندالّهى كهياى برايهوه.( نارهزاى و كَلهيى) كُهو مندالّهى، كهبهر تؤيى ئهو مهالعونه كهوتوه. (هـستدهربرين) تهعدامان للكهس نهكردوه. ( ياكانهكردن) مالّى كهسمان نهخواردوه.( ياكانهكردن) دهركامان كراوهوه بو هـهمو ئاوارهيك. (بهزهيى) وهلاّهى يهايوهندى به ئيسلامهوه نييه.(سويندخواردن) يُيمهـ شارهكانمان ويّران بوو.(كلهى + هـهتدهربرين) ئهوهى وادهليّت درودهكا. (تاوانباركردن) كُكگهر هـمووى دو مزكاهوتى تيانهبوو يهكى تيابوه.(نرخاندن) ياءكيان نههاته جواب.(كلهيى + نارهزای) كورد مندالهكهيان لههـموو تورك بهاشهرهف و به ناموستره.(توانج ليدان) 


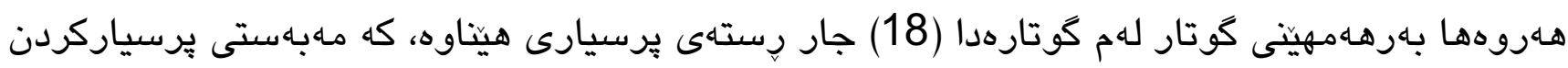

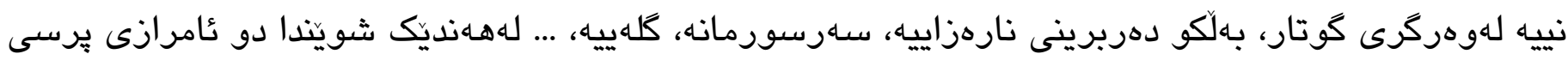

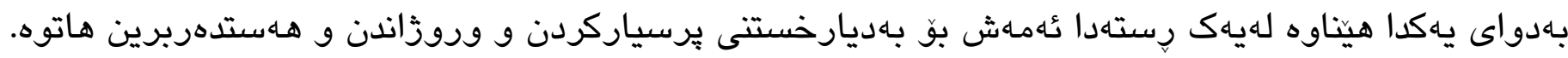

$$
\begin{aligned}
& \text { جِّن دهستكارى ئيشى خوا دهكه؟ (سهارسورمان) } \\
& \text { يوِ ئهم تهعدا كَهوره دهكهى؟ (نارهزايى) } \\
& \text { بووامان ليدهكهن؟ (هـلَّهون + بيّزارى) }
\end{aligned}
$$

جهاندهها كهس لهوّزى دايكوباوكى بيّبهشبو (نرخاندن)

$$
\text { كا دهولّهتى ئيسلامى؟(يرسيارى) }
$$

يهنى لهبهرجي تاوانمان جييه؟ ( برسيارى)

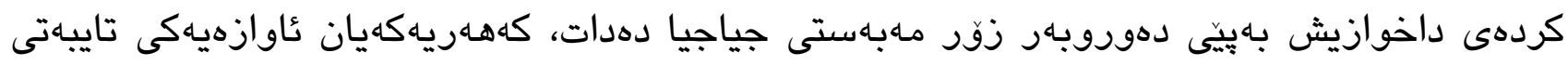

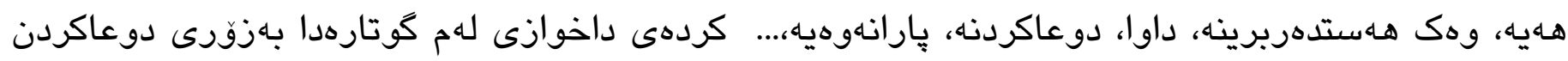

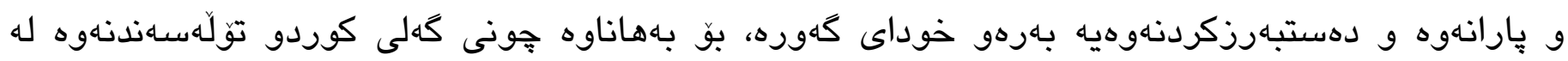
زولّمكهران.

$$
\begin{aligned}
& \text { يارهبى خودايه حهقمان لهم توركيايه بسينى. (يارانهوه) } \\
& \text { حهقى ئهم ميللهتهى ليِيستينى. (دوعاكردن) }
\end{aligned}
$$

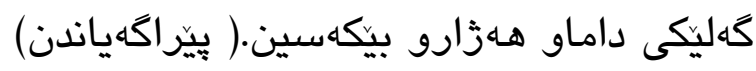

$$
\begin{aligned}
& \text { ئاويكِ بكه بهم ئاكره. ( بارانهوه و دوعاكردن) }
\end{aligned}
$$

ياردبى خودايه خوت بهكورديهتى خلقتكردوين ديفاعمان ليّكه. ( پاراستن + دوعاكردن)

$$
\text { ياالله ئيمانما رِوو لهتوين ودينهكهى محمدمان هـلبّزاردوه. (ص) ( موسلمان بون) }
$$

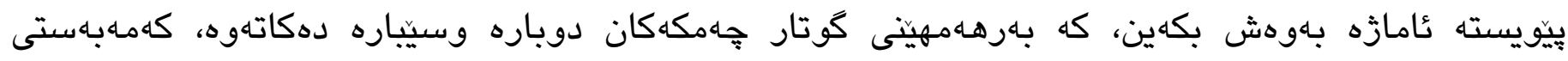

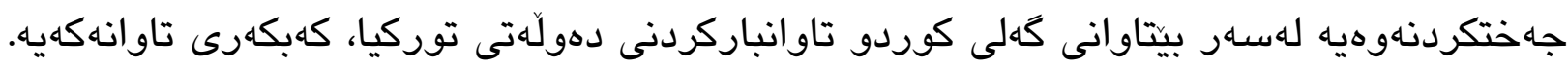




\section{2 هوختهى كوتثارمكهى مهلا ناراز}

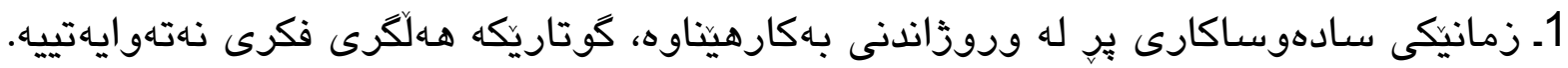
2. جهخت لهسهر بيتّاوانى كهلى كوردو تاوانباركردنى ئهردوّان دهكاتهوه، ئهمه دلنياكردنهوهى كويكَره، يان ئاستى متمانه باهخوبونهوه.

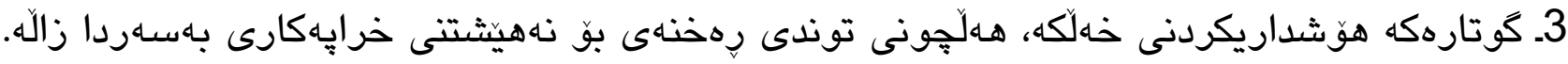
4. له باسكردنى ميّزو بايهخدان به رِابردو دهكه رِيتهوه بو ميزّوى كورد له رِيكّهى باسكردنى ئهو ستهمانهى،

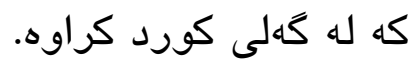

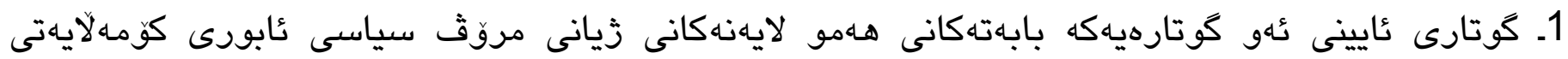

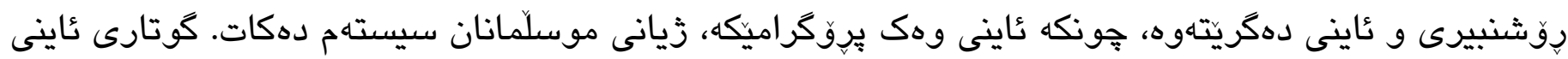

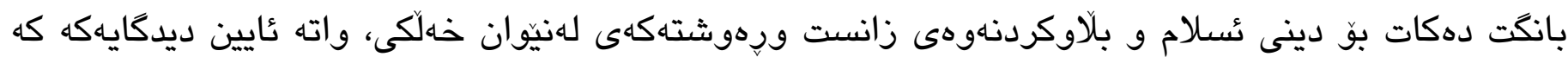
كونتروّلى بيروكهكانى تاك و كاروبارهكانى دهات.

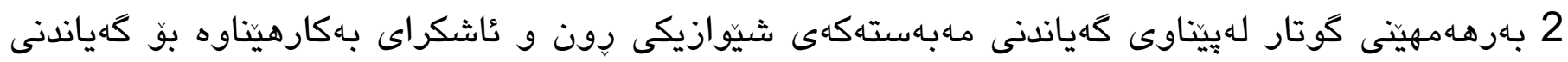

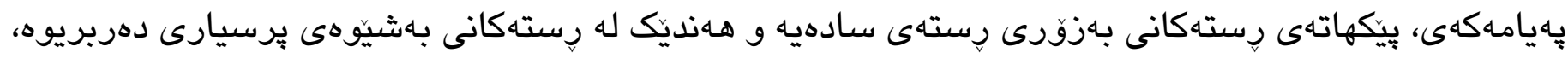
بهلام مهبهستى سهرهكى رستهكه برسيارنييه، بهلكو دهربرينى نارهزاييه، سارسورمانه، كلهييه،... لههاندئيك

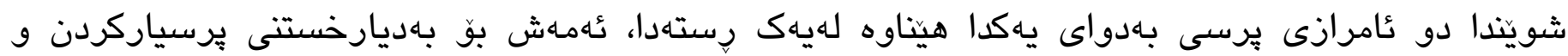
وروزاندن و هاستدهربرين هاتوه. لهرووى سينتاكساوهش هـنديكجار ياسا سينتاكسيهكان تيكدهشينينت و

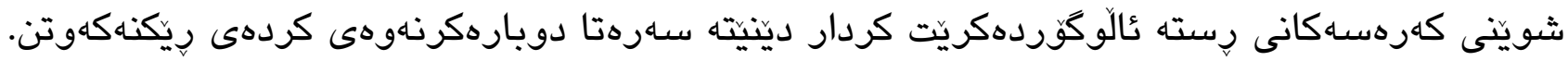

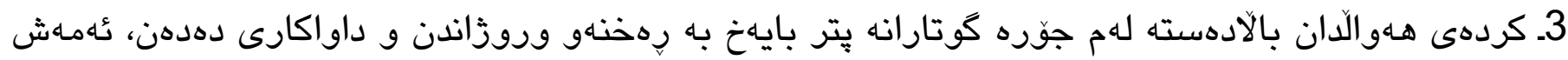
كاريكى ئاساييه، هـروهها كردهى داخوازى لهم كوتارهدا بهزوقىى دوعاكردن و پِارانهوه و دهستبهرزكردنهوهيه

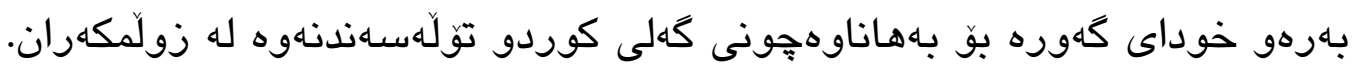

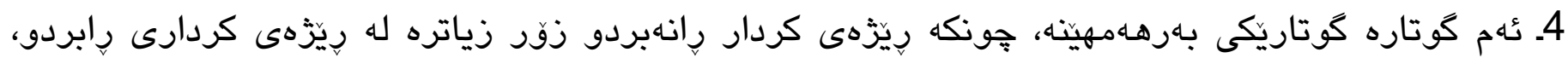

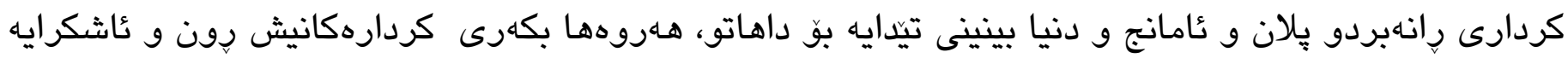




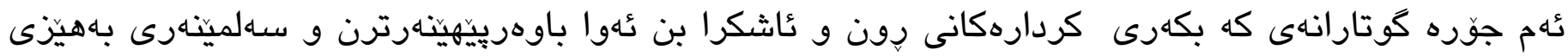

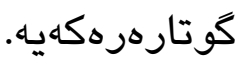

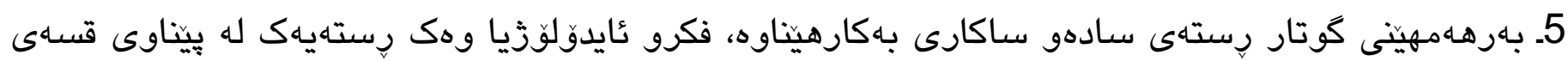

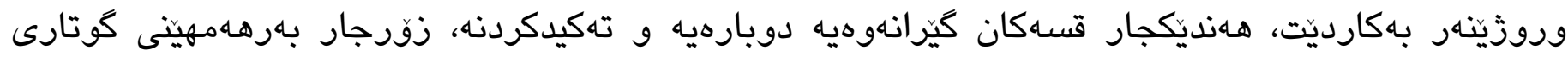

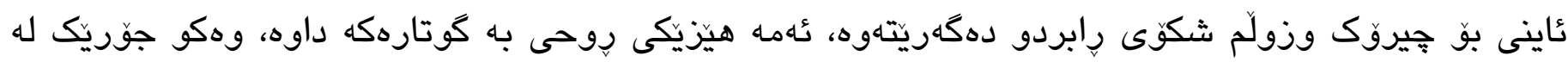

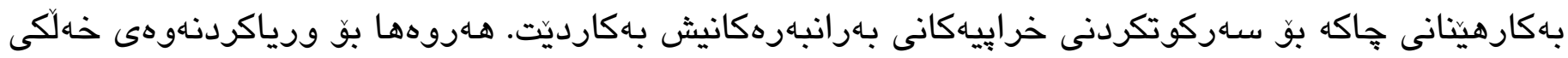

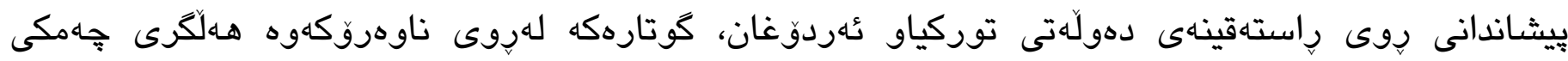

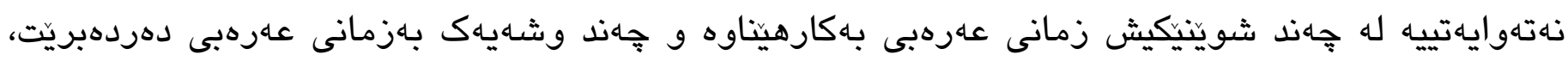
كُهمها ش دهگهريتهوه بو كاريكهرى قورئان.

\section{كورته كوتارى ماموّستا مهلا تُاراز دهربارمى ثيداثلكردثى هيّرشى توركيا بوّ سهركوردان}

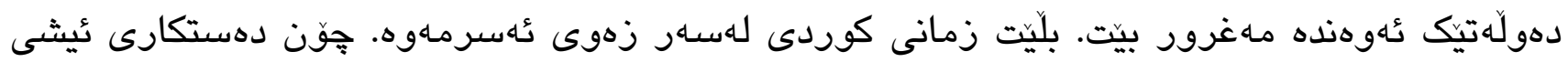

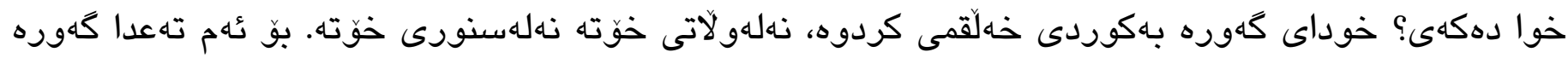

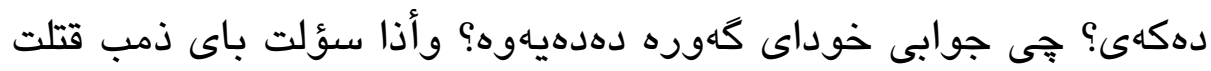

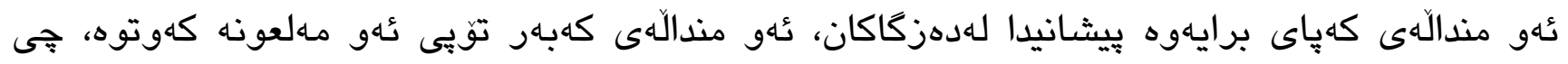

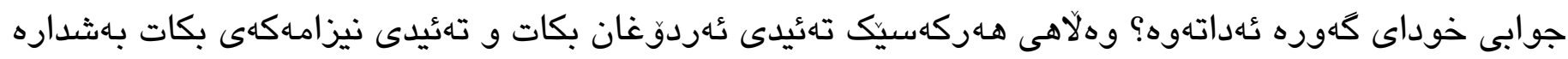

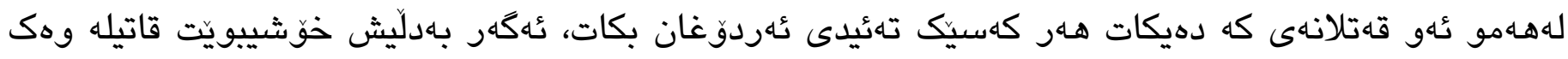
كئو

جاريكيان سهدام ديتو سورهتى ئهنفال جيّبه جيّدكات بهاسهار كوردا بهكافرمان دهزانيى و مزكهوتهكان دهروخينّى و دولّي عُهنفال

جاريكيان تورك ديّتو سورهتى فهتح جيّبهجيّدكات لهسهرمانا و دهلّي ئهمانه لهناويان دهبهم كافرن بو يهاعنى

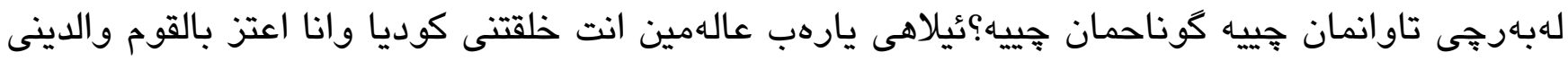
تؤبهوردى خهلقتكردوم شانازى دهكهم بهكوردييهتى خوم قهوميهتى خوم بهدينهكهى خوم كه موسلمانم.

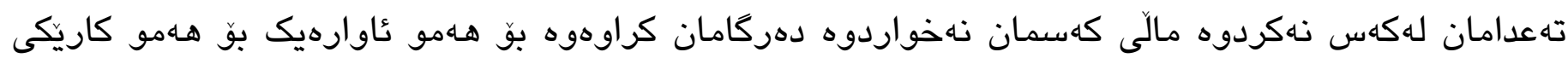
نهخوازراو دهركامان كراوه بوه. بووامان ليدهكه؟ وهلاهى بهايوهندى به ئيسلامهوه نييه. تهنها زمانمان كورده دهان

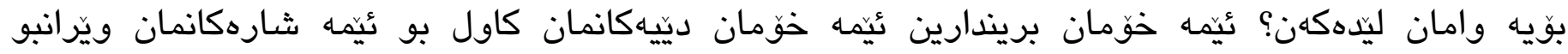

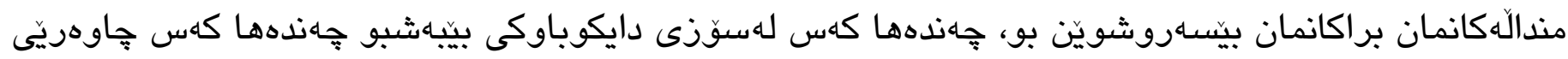




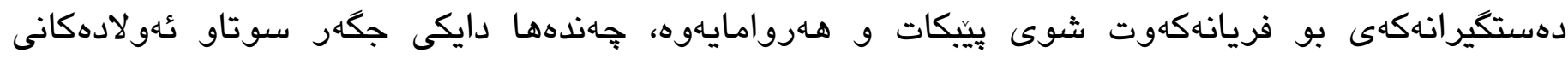

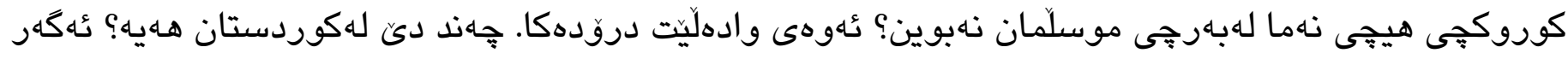
هـاموى دو مزكاهوتى تيانهبو ياكى تيابوه، يهك مالدروستكرابيت بهرده نويَّى تيابوه. بهس تهنها لهبهر تُهوهى كوردين، ئيمها دوّتمان نييه. برايان خوشكان نهغهرب و نهشهارق دوستمان نييه. (22) دهولّهتى عهرهبى (50)

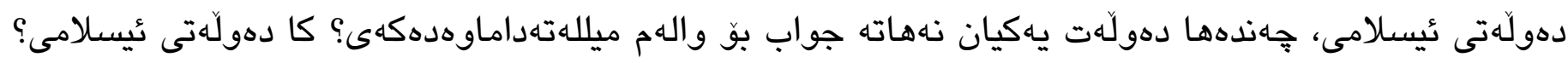

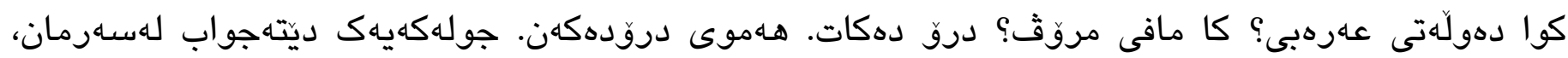

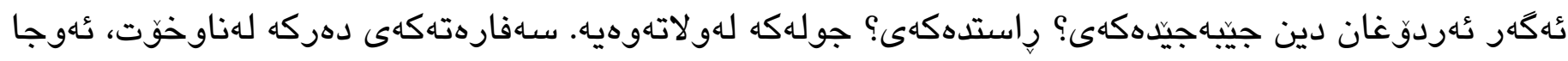
بلحي لهكورد دهدهم.

كورد مندالَكهيان لههـمو تورك بهشهارهف و به ناموستره. لهههمو تورك ئيماندارتره. مزكَهوتهانمان

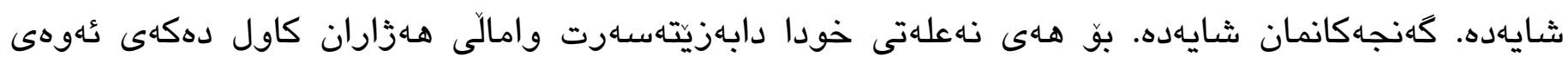

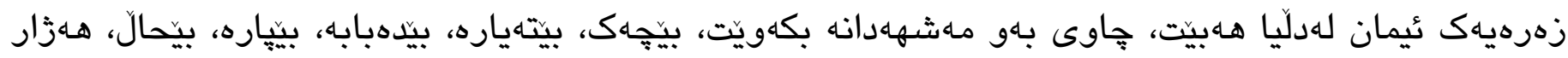

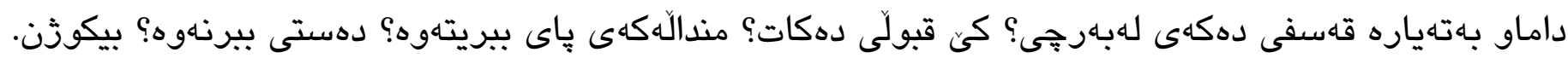

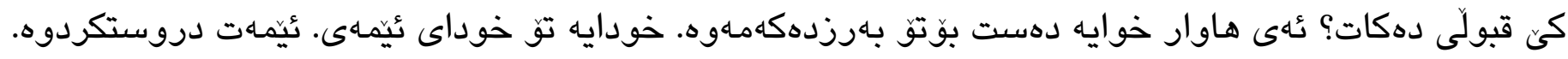
ياالله ياموجبت دعوات وياقاضى حاجات تقبل دوعائنا ياالله

يارهبى خودايه حهقمان لهم توركيايه بسينى. حاهى ئهم ميللهتهى ليّبستينى. يارهبى خودايه ئيّمها

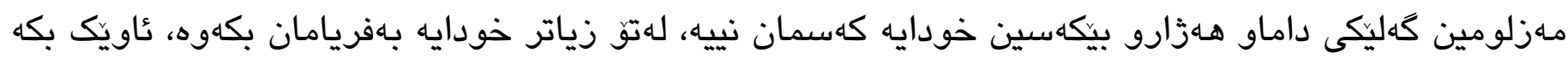

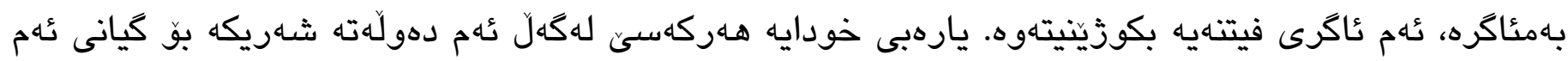

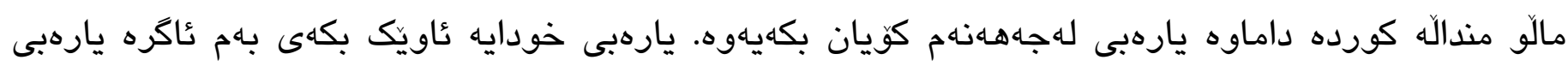
خودايه خوّت بهكورديهتى خلقتكردوين ديفاعمان ليبكه يالله لهئيمانمانا رو لهتوين ودينهكهى محمدمان

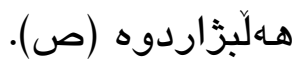




\title{
Analyzing Religious Speech in Terms of Speech Act Theory
}

\author{
Sherwan Hussein Hamad \\ Department of Kurdish, College of Basic Education, University of Raparin, Rania, Kurdistan \\ Region, Iraq. \\ E-mail: sherwan983@uor.edu.krd
}

\section{Talar Sabah Omer}

Department of Kurdish, College of Education, University of Koya, Koya, Kurdistan Region, Iraq.

E-mail: talar.sabah@koyauniversity.org

\begin{abstract}
:
Every Friday, articles were presented at mosques, and the subject of the articles involved all aspects of human life, political, economic, social,...Any phenomenon in the society is mentioned in religious speeches. These articles will be part of religious discourse in Kurdistan, one of the subjects we have chosen for this investigation and we will study it from the perspective of a speech by Mala Araz about condemning the Turkish attack on the kurds. The aim of our study is to analyze religious discourse from a pragmatic perspective to achieve the goal that we have analyzed in the methodology, and we have received an example from the book" Mala Araz", which is in the context of the central Kurdish language kurmanji dialect.
\end{abstract}

Keywords: Speech Act Theory, Religious Discourse,, Discourse Analysis, Pragmatic. 


\section{سلوهجاومكان:}

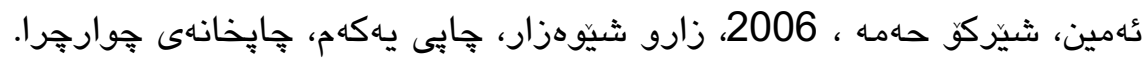

توفيق، قهيس كاكل،(1995)، جوّرهكانى رستهو تيوّى كردهقسهييهكان، نامهى ماستهر، زانكوَى سهلاحهددين.

دزهيى، عبدولواحيد موشير, (2011), زانستى يراكماتيك، جايى يهكهم, جايخانهى پاك, هـوليّر.

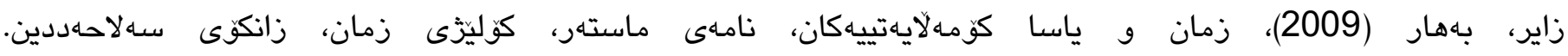

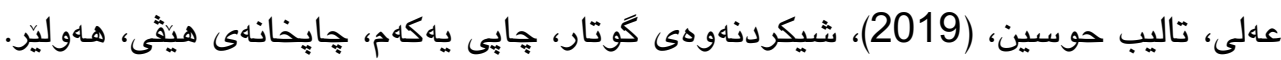
عبدولكهريم، كاوه، (2007)،( زمان و بِروّسهى بِيِونديكردن)، كُوثارى رامان، ز. (118) فتاح، محمد معروف، (زمانهوانى)، دار الحكمة، 1990.

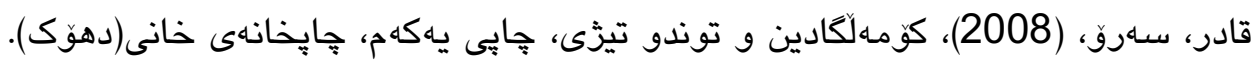

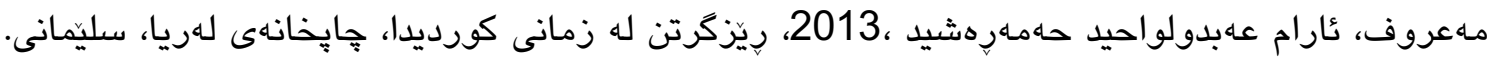
مهاهمود، ئاثيستا كهمال، (2009)،يِراكماتيكى رستهى بِرسياروفهرمان له زمانى كورديدا، جإِخانهى رِنج، سليمانى.

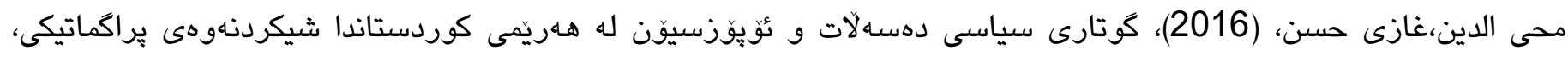
نامهى ماستهر، زانكوّى سوران.

مـهلا عبدالكريمى مدرس و فاتح عبدالكريم و محمدى مهلا كريم (1976)، ديوانى نالى، جإيخانهى كورِى زانيارى كورد-به غدا. مهلا عبدالكريمى مدرس و محمدى مهلا كريم (1984)، ديوانى مهحوى ،جايى دوهم، جايخانهى كورىى زانيارى كورد-بهغدا . 


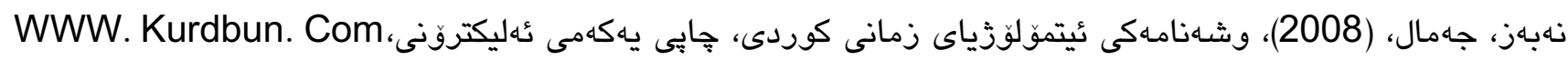
ناوخوّش، سهلام، (2007)، ثَايين و زمانتاسى، جايبى يهكهم، هـوليّر. شرفى، سلوى، (2010)، تحليل الخطاب و الرسائل السياسيه فى وسائل الاعلام، مركز نشر الجامعى، تونس. عكاشه، محمود، (2005)، لغه الخطاب السياسى دراسه لغويه تطبيقيه فى ضوء نظرية الاتصال، دار النشر للجامعات مصر، مصر. والغزالي، عبدالقادر، (2003)، (اللسانيات و نظرية التواصل)، دار الحوار للنشر و لتوزيع، الطبعة الاولى.

Barbara Johnstone, 2008, Discourse Analysis, Second Edition,Blackwell.Publishing.

Cook,Guy( 1989) Discorse,Oxford university,paress

G.Leech. ( 1983 ). Principle of pragmatics. London: longman 